\title{
Characterization of Fired Clay Bricks for an Economic Contribution of the Exploitation of Thicky Clay Deposit
}

\author{
Ibrahima Diao1, Mababa Diagne ${ }^{2 *}$, Ibrahima Dia ${ }^{2}$ \\ ${ }^{1}$ Enterprise AKDAR BTP, Dakar, Sénégal \\ ${ }^{2}$ Ecole Supérieure des Mines de la Géologie et de l'Environnement (ESMGE), Université Amadou Mahtar MBOW de Dakar, Da- \\ kar, Sénégal \\ Email: contact@akdarbtp.com,www.akdarbtp.com, ^mababa.diagne@uam.edu.sn
}

How to cite this paper: Diao, I., Diagne, M. and Dia, I. (2021) Characterization of Fired Clay Bricks for an Economic Contribution of the Exploitation of Thicky Clay Deposit. Materials Sciences and Applications, 12, 389-416.

https://doi.org/10.4236/msa.2021.129027

Received: July 31,2021

Accepted: September 23, 2021

Published: September 26, 2021

Copyright $\odot 2021$ by author(s) and Scientific Research Publishing Inc. This work is licensed under the Creative Commons Attribution International License (CC BY 4.0).

http://creativecommons.org/licenses/by/4.0/

\begin{abstract}
Clay materials from Thicky in Thiès district (Senegal) are very abundant and could be used for the production of clay brick for the construction industry in Senegal and the surrounding countries. The geophysical, geotechnical, and thermal studies carried out did lead to a better comprehension of the potential of the area for clay production. It also allowed determining the physical and chemical characteristics of the clays for their use in order to make fired clay bricks. Different types of fired clay brick were produced with Thicky's clays. The study of the physical, mechanical and thermal parameters of these raw materials and bricks has given very satisfactory results compared to the standards in use. It is noted a good ceramic behavior, and there is no deterioration observed after firing at $900^{\circ} \mathrm{C}$ until low residual moisture of about 3\% (on a dry basis), a smooth texture with a beautiful appearance, a low loss on ignition, a low shrinkage value of less than $1 \%$ (dry), moderate water absorption and also good compressive strength. The study of thermal properties on a brick wall by the asymmetric lime plane method gives satisfactory effusivity and thermal conductivity values which are respectively equal to $746.48 \mathrm{~J} \cdot \mathrm{K}^{-1} \cdot \mathrm{m}^{-2} \cdot \mathrm{s}^{-1 / 2}$ and $0.42 \mathrm{~W} \cdot \mathrm{m}^{-1} \cdot \mathrm{k}^{-1}$ with a thermal resistance of $0.0028 \mathrm{~m}^{2} \cdot \mathrm{K} \cdot \mathrm{W}^{-1}$.
\end{abstract}

\section{Keywords}

Clay, Bricks, Fired, Thicky, Construction, Water Absorption, Capillarity Absorption, Compressive Strength

\section{Introduction}

Due to economic issues, Senegal faces a major challenge in providing decent 
housing for all applicants. There is currently a housing deficit estimated at 125,000 units [1]. For decades, the construction industry has focused on developing new materials in order to minimize the environmental impact and improve building insulation envelopes.

In the building industry intended for residential use, the bricks designed with Portland cement are systematically chosen. For those bricks, the value chain from production to implementation on the various sites, requires significant resources and logistics. Almost all of the masonry in today's buildings in the country is done with a combination of concrete, bricks and plaster consisting of cement, sand, gravel and water. The depletion of conventional aggregate deposits, the high construction costs as well as the negative effects of the cement industry on the environment are so many problems to be solved for a sustainable development.

The objective of this study is to propose an alternative to the use of Portland cement and crushed gravel for the construction of bricks by developing a sustainable method with the use of clay materials from Thicky in Thiès district. This area is well known for its significant potential of clay materials, for the production of fired clay bricks.

This work's aim is, then, to enhance the value of local clay raw materials by developing widely distributed ceramic products.

The drilling and public works company (Société de Forage et de Travaux Publics (SFTP)) holds a prospecting authorization in this area with the goal of promoting the development of construction products based on local clay raw materials. SFTP carried out geophysical and geotechnical field studies which gave satisfactory results in terms of ceramic quantity and quality.

The production of bricks was made possible with the involvement of the SOFAMAC Company which optimized the use of yellow clays and gray clays for the production of several types of fired clay bricks whose physical, mechanical and thermal characteristics meet the standards in use.

The comparative study between a construction with classic concrete blocks in Portland cement and a construction with fired clay bricks has given results consisting in a lower cost, better preservation of the environment, greater thermal comfort and a considerable social impact.

The enhancement of thermal properties may strongly impact on the energy performance of the building, and the lightweight bricks for infill walls reduce building structural requirements [2].

The demands of the residential sector account for about $26.5 \%$ of the total energy consumed in the EU [3], with a large proportion of this energy used for heating, ventilating and air-conditioning.

\section{Presentation of the Study Area}

The village of Thicky is located in Diass commune with approximately 34,829 inhabitants. The location of the study area (Figure 1) is characterized by rugged 


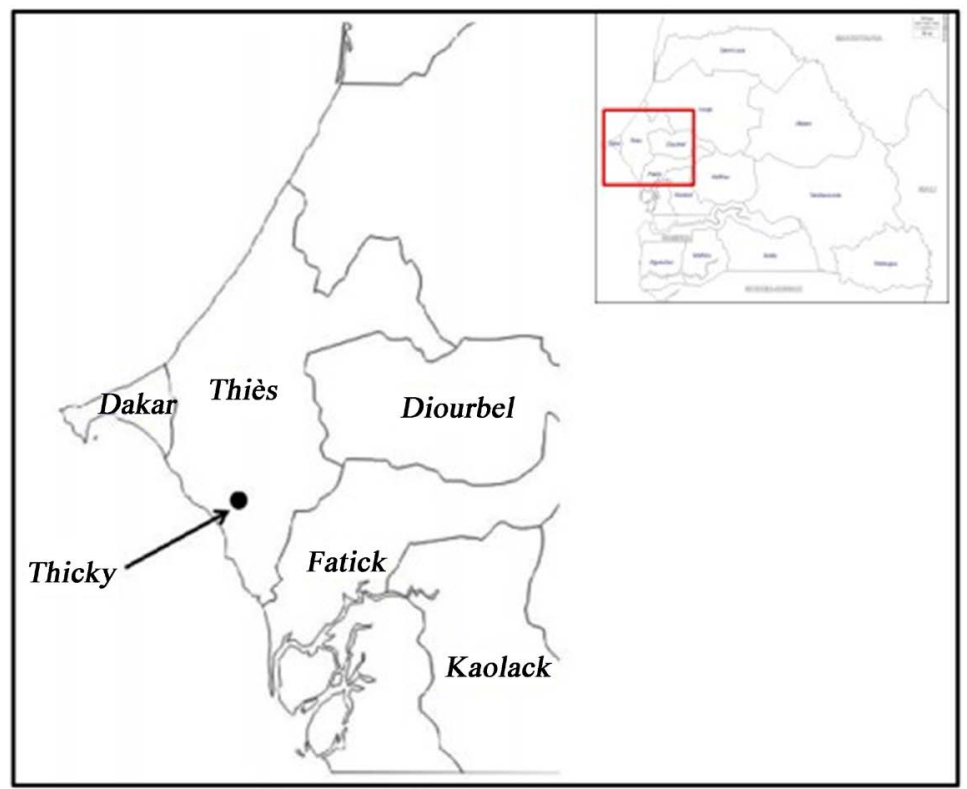

Figure 1. Geographical location map of the village of Thicky in Thiès region.

terrains with a geomorphology consisting of small hills. The altitudes in the sector vary from 42 to $108 \mathrm{~m}$. Located at $4 \mathrm{~km}$ west of the national road (RN1 Dakar-Kaolack) between the cities of Diass and Sindia, the Thicky area is characterized by clay hills.

Hydrographically, the area is crossed by small intermittent streams which flow at its pic of the rainy season. The rainy season lasts from July to September with rainfall of around $500 \mathrm{~mm} /$ year. The climate is Sudano-sahelian and the temperatures vary between $20^{\circ} \mathrm{C}$ and $40^{\circ} \mathrm{C}$.

The clays and sands of Thicky belong to the Maastrichtian era and constitute, in this region, the stratigraphic level of the summit of the Diass Horst. Their facies are equivalent to the detrital levels (sands, sandstones) of the central part of the Horst [4]. Argillaceous series have long been known around the village of Thicky in the Ndangdang quarry, to the south. They belong to the undifferentiated Upper Cretaceous.

\section{Geotechnical and Geophysical Prospection, Ceramic Characterization Tests and Results}

\subsection{Delimitation of the Study Area}

A study area has been identified and the corresponding prospecting authorization has been issued by the Senegalese Ministry of Mines and Geology. The study perimeter covers an area of thirty-seven and a half hectares ( $37.5 \mathrm{ha}$ ). Table 1 gives the coordinates of the permit.

Figure 2 gives the situation of the permit in the geological context of the site.

\subsection{Geotechnical Drilling and Sampling}

This part of the work consists in carrying out geological prospecting campaigns 
Table 1. Study perimeter corner points coordinates (UTM WGS 84 Zone 29 projection).

\begin{tabular}{ccc}
\hline Corner points & Easting & Northing \\
\hline A & $1,616,557$ & 277,885 \\
B & $1,616,020$ & 278,292 \\
C & $1,615,821$ & 277,999 \\
D & $1,615,953$ & 277,695 \\
E & $1,615,938$ & 277,566 \\
F & $1,616,172$ & 277,303 \\
\hline
\end{tabular}

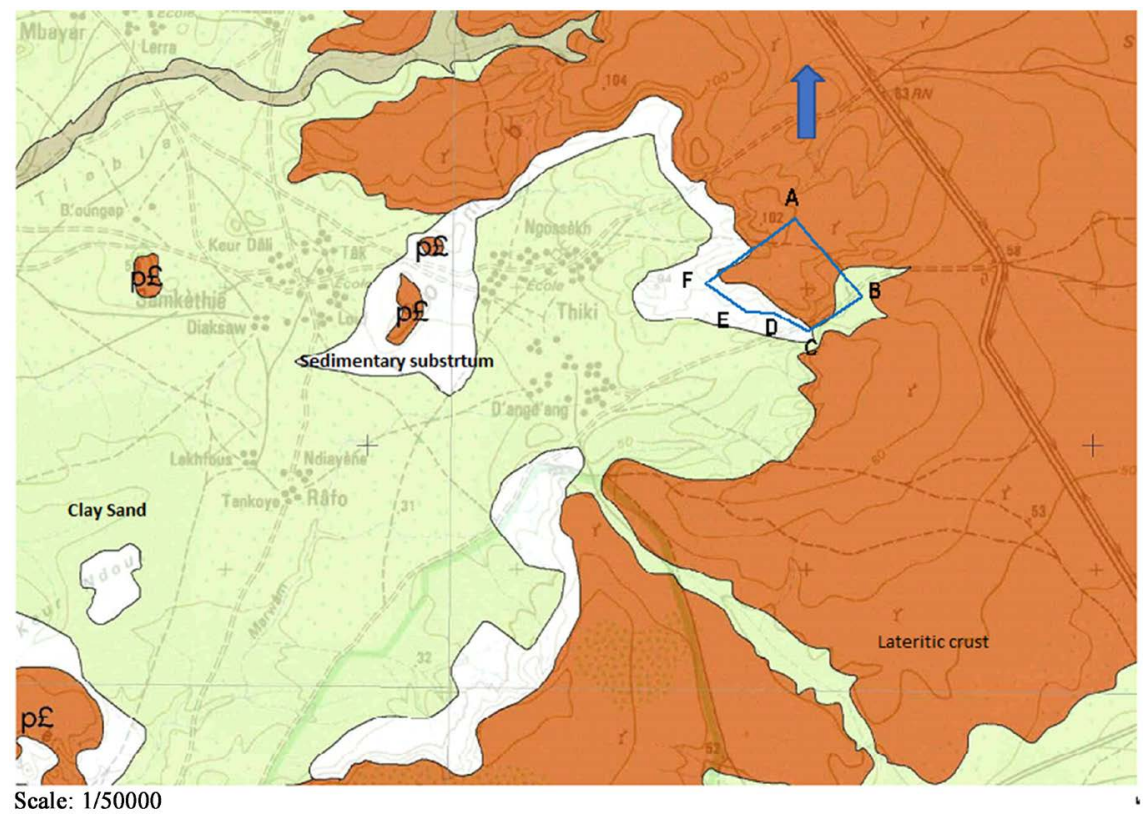

Figure 2. Location map of the study area onto the geology, Map extracted from the Bargny sheet at $1 / 50.000$ [5].

using core drillings targeting clay formations in the perimeter of the permit. These campaigns enabled to determine the location, the shape, the dimensions and the quantity of the clay deposit. It also allowed determining their geological and hydrogeological conditions, the characteristics of the material that can be exploited in the various parts of the deposit. Several core drilling holes were carried out with the percussion manual coring system (Figure 3) and the general lithological profile is shown in Figure 4.

\subsection{Geophysical Studies}

The geophysical survey was done by electrical resistivity tomography which is a direct current geophysical prospecting method. It allowed obtaining an "electrical image" as vertical section (2D and 3D) of the subsoil, from surface resistivity measurements. The investigation is carried out on the base of electrical profiles with the Terrameter LS Lund Imaging System G70 2D resistivity meter equipped with four rolls of cables of $100 \mathrm{~m}$ each. 2D acquisition uses a large number of 


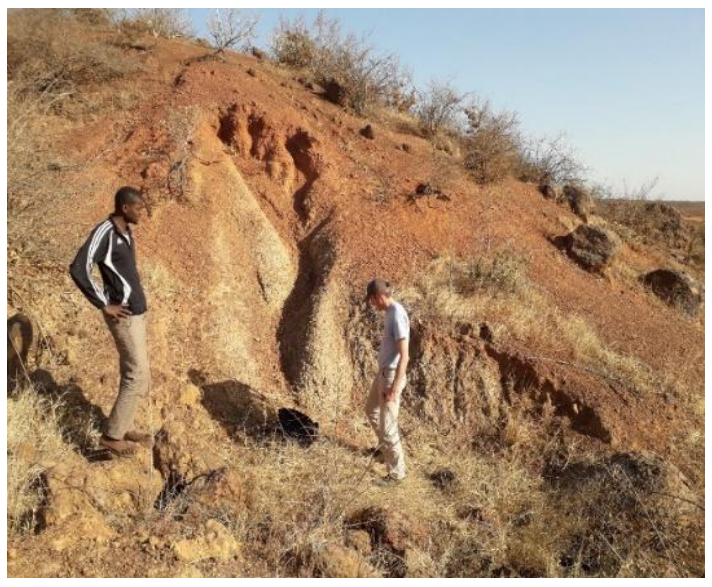

Drill hole TK1.1

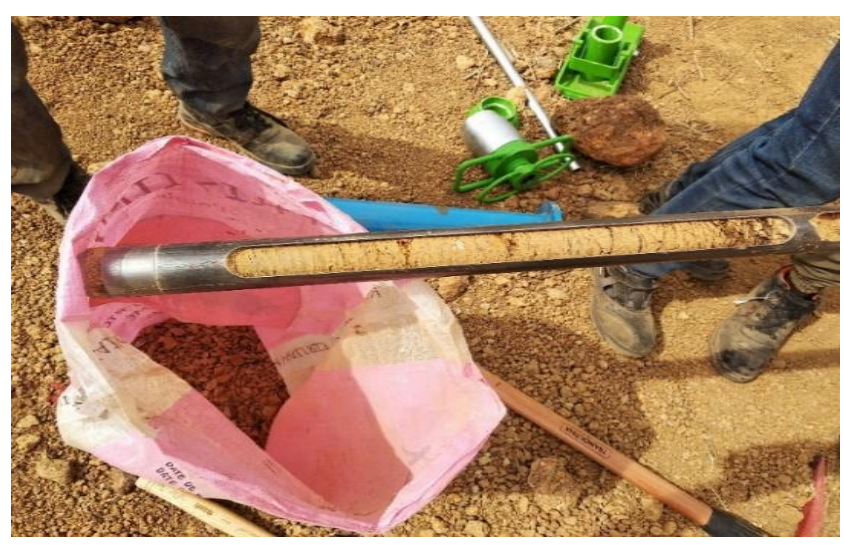

Drill hole TK1.4

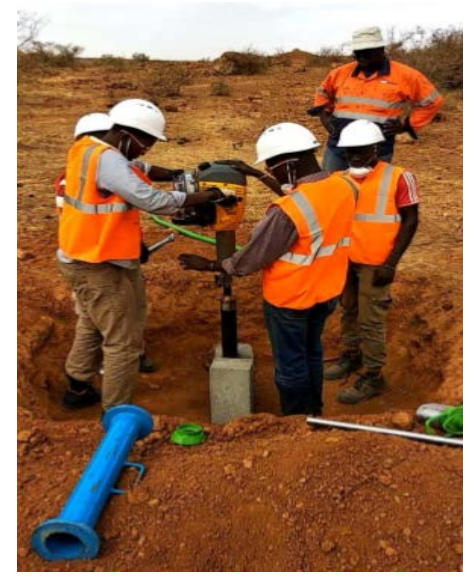

Drill hole TK1.2

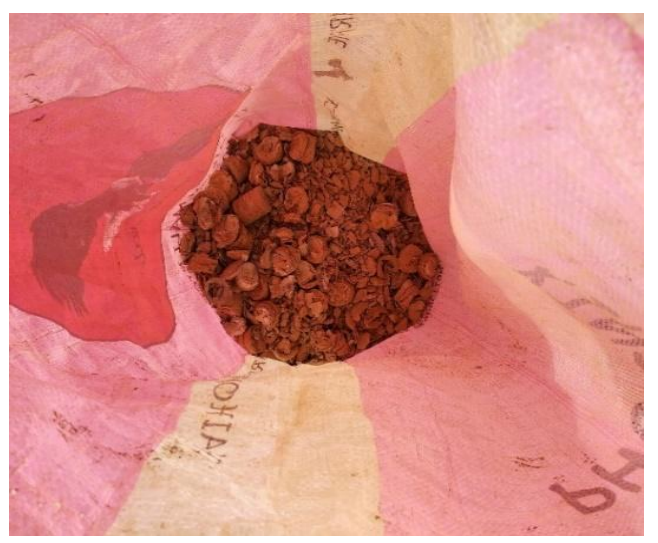

Drill hole TK1.4

Figure 3. Illustrations of some of the manual drilling carried out.

regularly moved electrodes connected to a multi-conductor cable, all connected to a resistivity meter. The electrodes are evenly spaced along the profile. Thirteen (13) electrical resistivity tomography profiles (Figure 5), distributed based on 1:50,000 scale geological mapping data, were performed [6]. The length of the profiles varies from 100 to $400 \mathrm{~m}$ long with spacing of $5 \mathrm{~m}$ between the electrodes. The acquisition device used is from Schlumberger.

Figures 6-8 give examples of vertical profiles obtained. The profile of Figure 6 , called the control profile, is used to calibrate the actual resistivity of the clays. It is centered on the TK1.1 mechanical borehole carried out on the site to a depth of $5.5 \mathrm{~m}$ at the point of GPS coordinates: $\mathrm{X}=277,318, \mathrm{Y}=1,616,192$. The clays encountered in this borehole would naturally have resistivity values between 10 and $20 \mathrm{Ohm} . \mathrm{m}$

The profile of Figure 7 shows, at surface, land of high resistivity (greater than 300 Ohm.m) corresponding to the lateritic crust. This cuirass continues deep in the western part. In the other part of the study area, it is noted the presence of a sedimentary substratum of low resistivity (less than $20 \mathrm{Ohm} . \mathrm{m}$ ) probably corresponding to clay.

The profile P11 in Figure 8 shows from the surface to a depth of about 15 


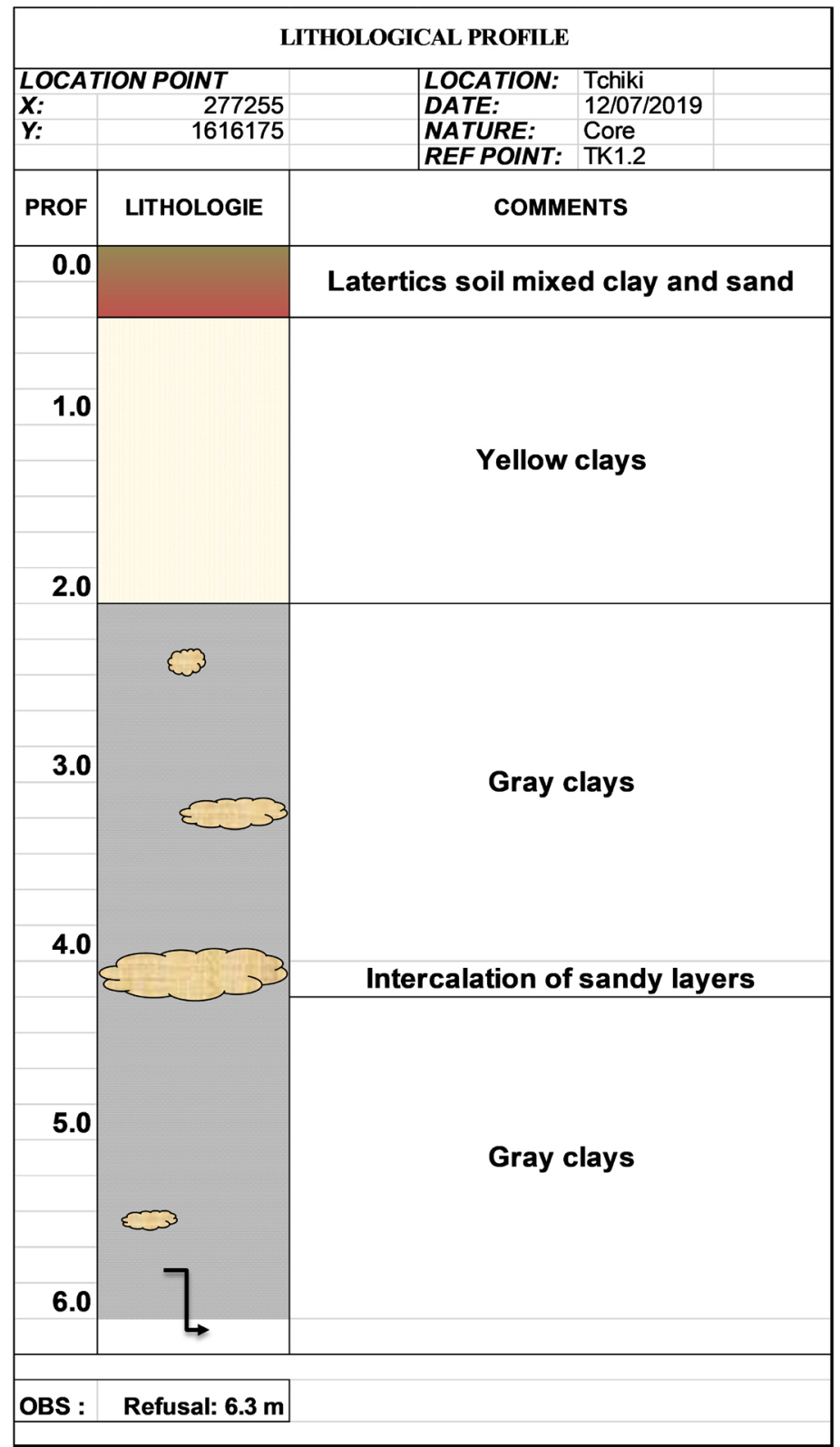

Figure 4. Stratigraphic log of the geology of the site.

meters, clay formations and sandy clays over the entire extent of the profile. The thickness of these clays tends to increase towards the North, where it reaches more than $20 \mathrm{~m}$.

The clay limits were not clearly seen except on profiles 11 and 12 . They do not allow the mapping of their inferior limit. The lateritic cover, corresponding to the depth of the roof of the clay layer, is shown on the map in Figure 9.

Geophysical survey shows that the studied area can be divided into three parts:

- The absence of clay formations in the north corresponding to the location of profiles 7, 10 and a part of profile 4;

- A part in the south with a decreasing thickness of lateritic cover towards the south-east allowing the clays to outcrop in the west part; 


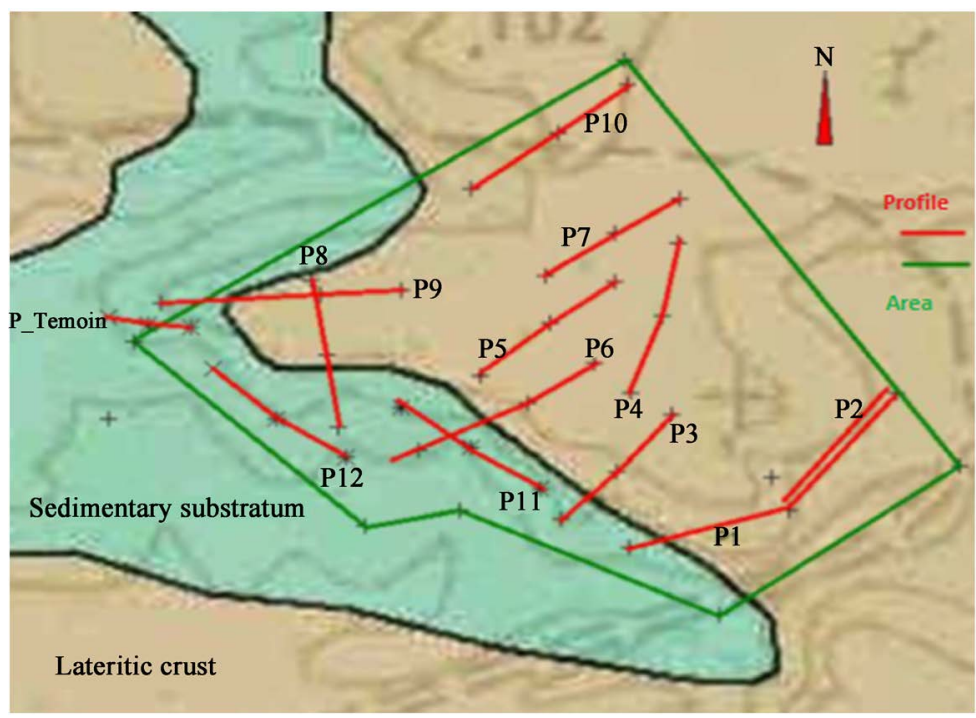

Figure 5. Location and positioning of the thirteen electrical profiles.

P13-TEMOIN

E SCHLUMBERGER 2D INVERTED MODEL (mean residual 17.7\%)

Distance $[\mathrm{m}] \quad$ W

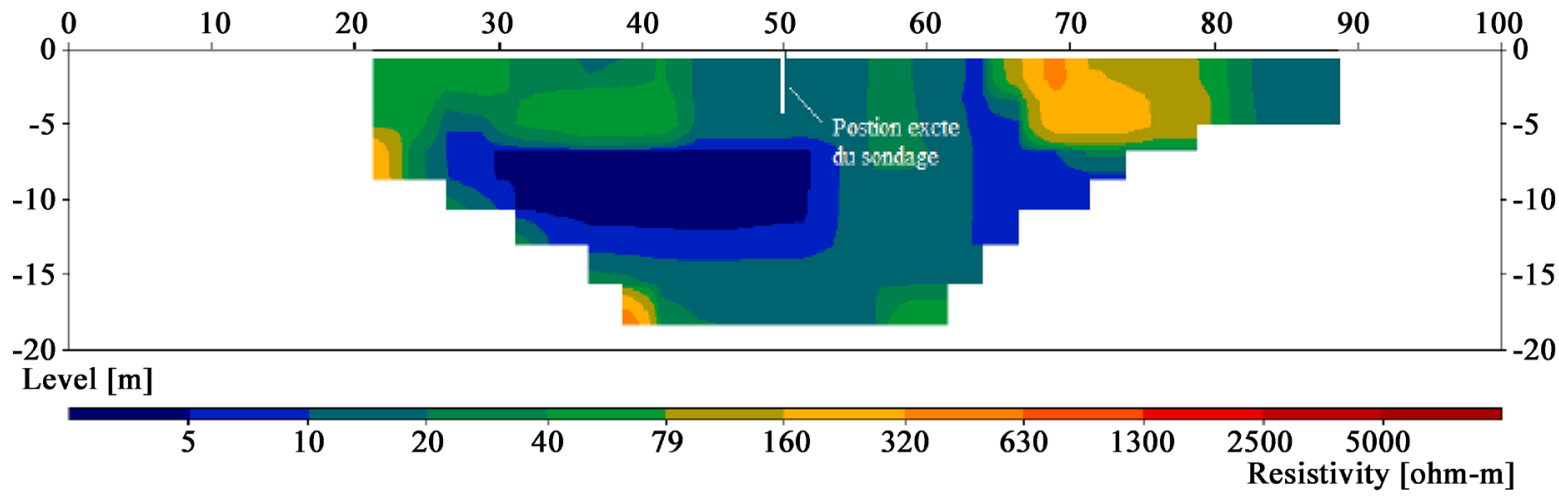

Figure 6. The control electrical section.

P1

W 2D INVERTED MODEL (mean residual 18.6\%)

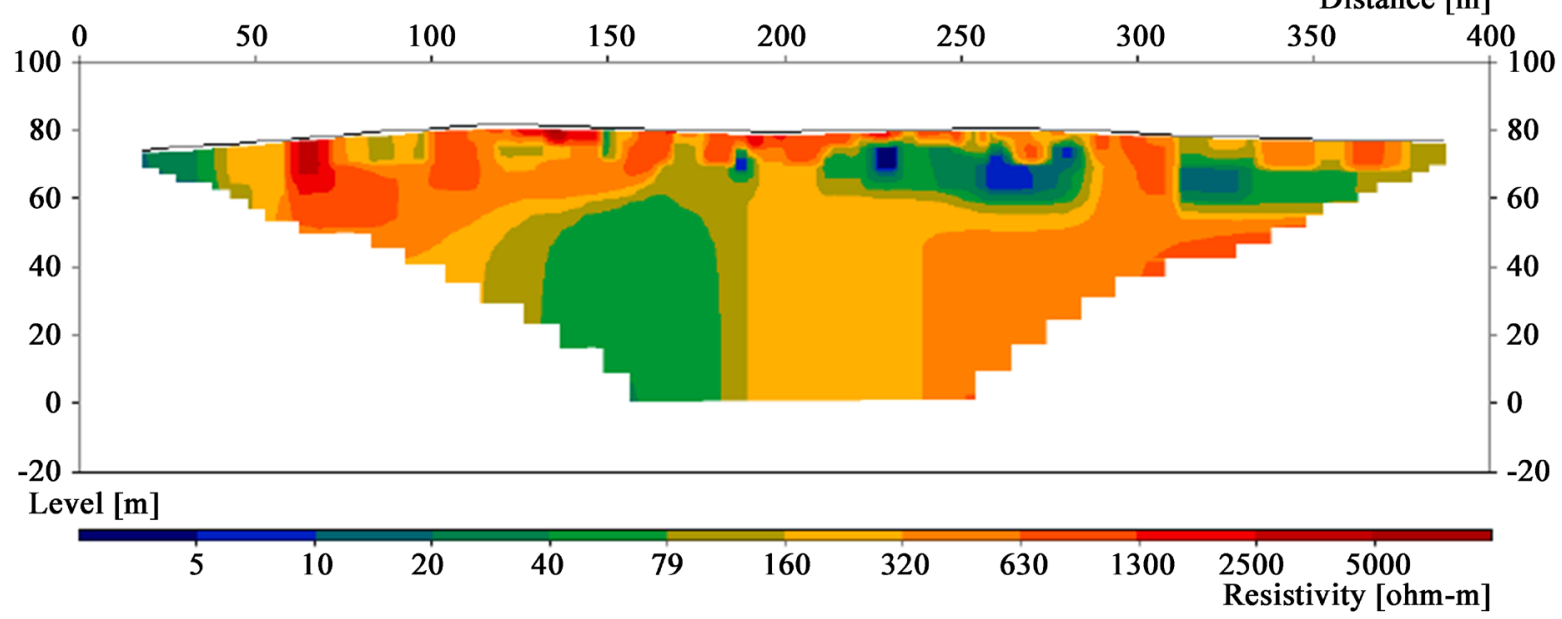

Figure 7. The profile P1 showing the lateritic crust at the surface. 
P11

S

2D INVERTED MODEL (mean residual 11.1\%)

$\mathrm{N}$

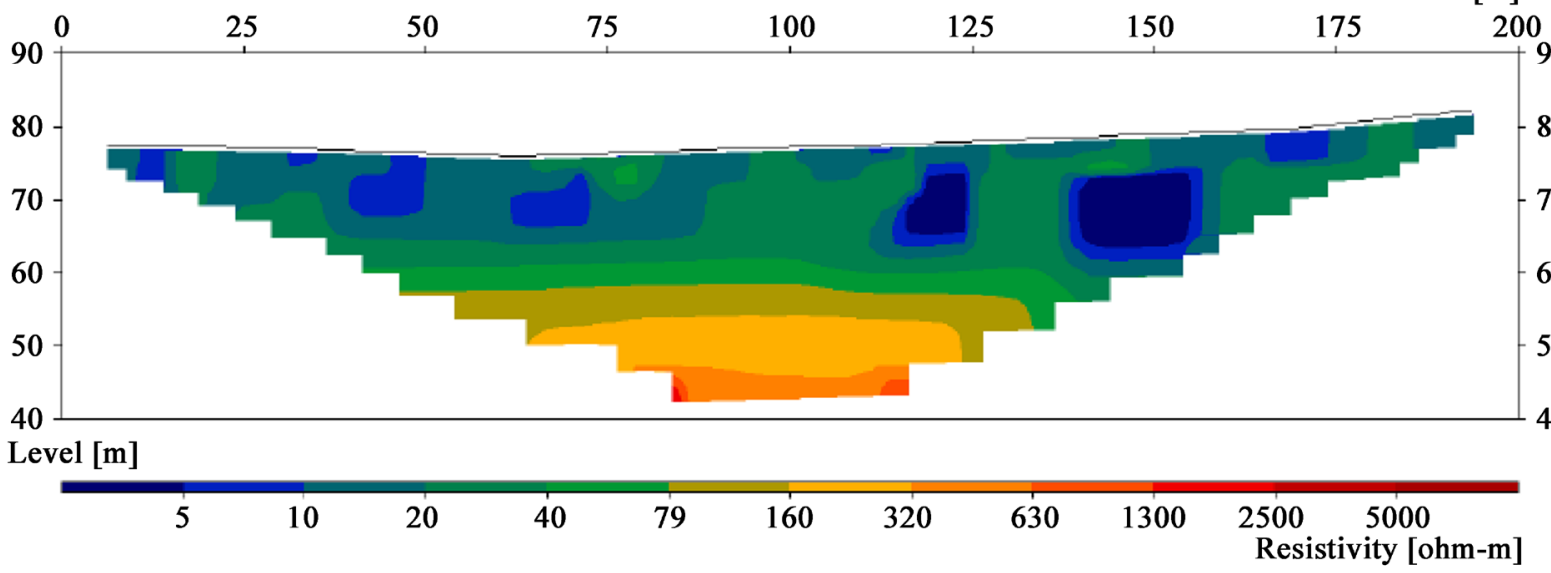

Figure 8. The profile P11 showing the thickness of the clay formations.

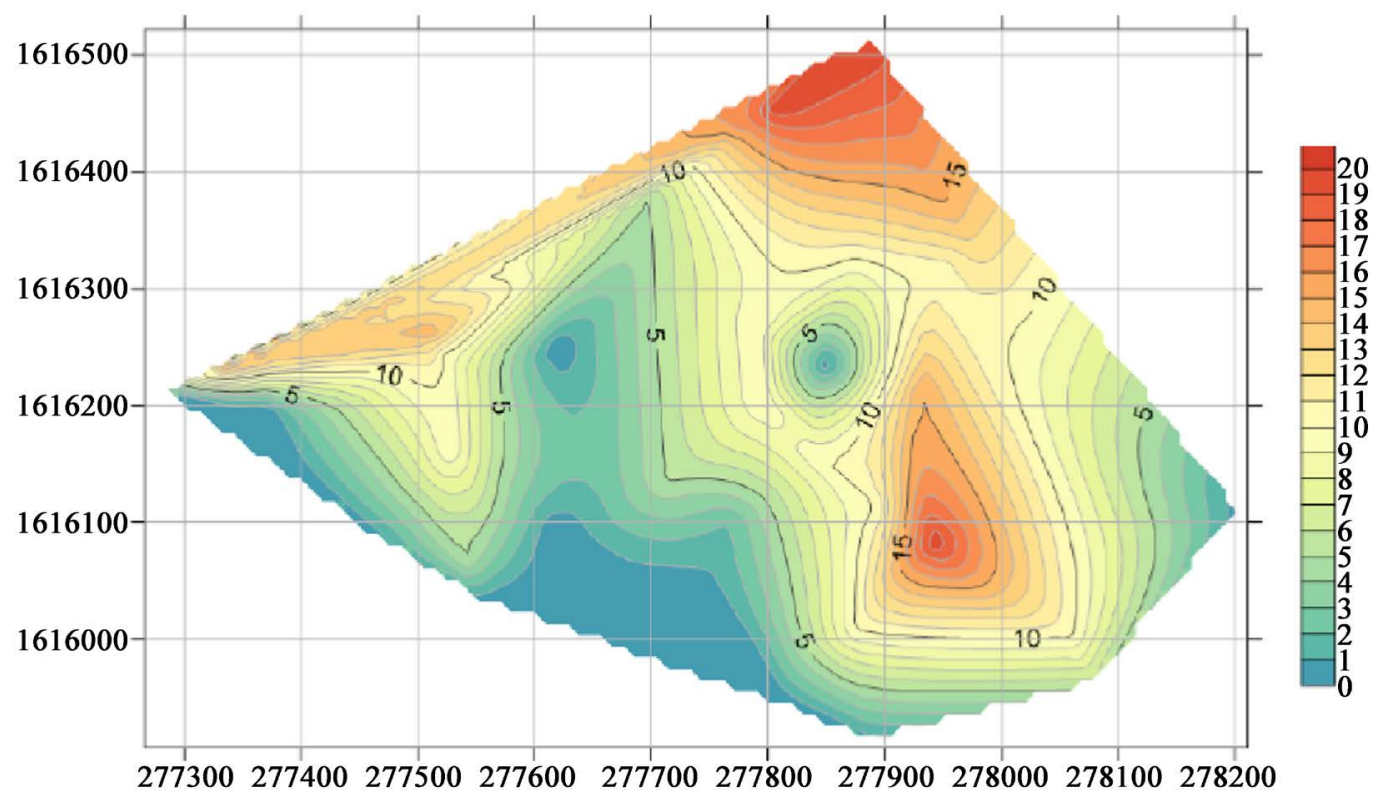

Figure 9. Lateritic cover thickness map corresponding the roof of the clay layer.

- The clay formations change locally into sandy-clay and even clayey sand towards the North, the East and the North-East. However, these sandy-clay formations can locally include clay. This occurs most often at great depth (more than $10 \mathrm{~m}$ ).

\subsection{Ceramic Characterization Tests}

The purpose is to monitor the behavior of Thicky clay during the process of brick production.

\subsubsection{The Grinding}

Three samples collected from the drill core carried out were crushed separately in the rolling mill. The aspect of the grinded material is shown in Figure 10. The 


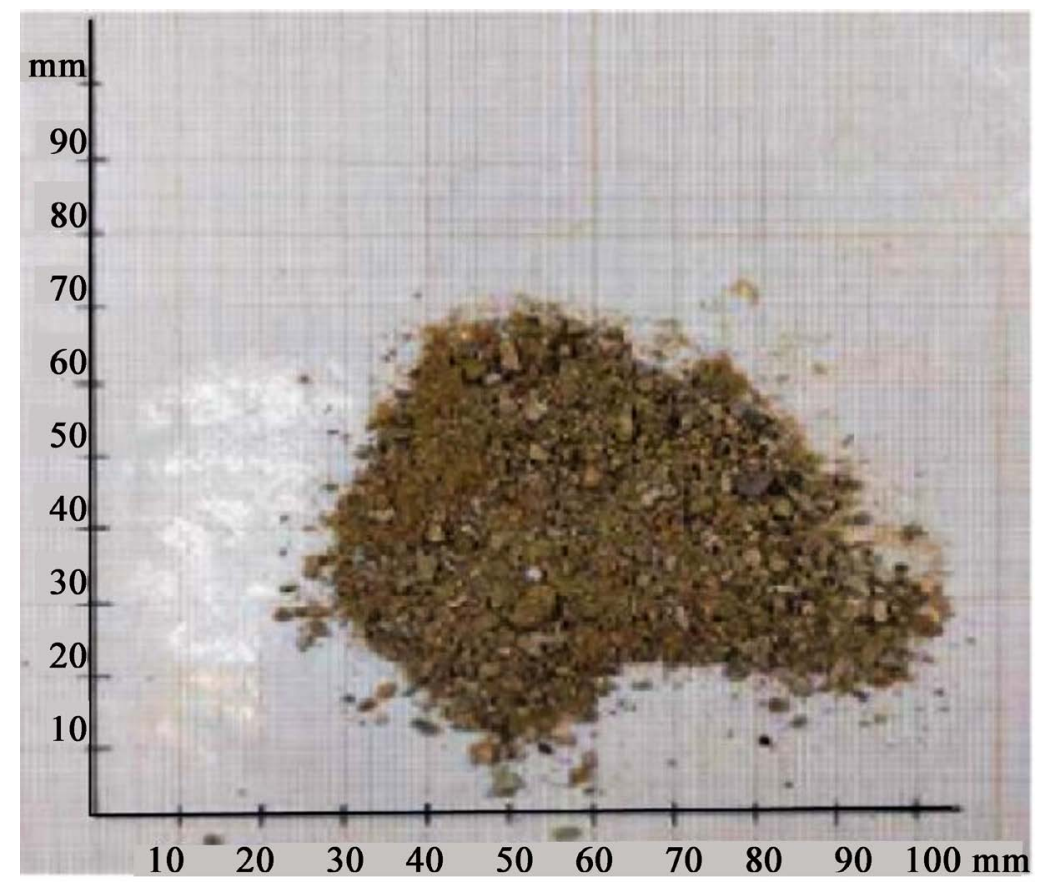

Figure 10. The grinded clay sample from the drill hole TK1.1.

description of the grinded clay raw material from TK.1.1 shows a clay free from organic matter, unpolluted, easy to grind with a maximum diameter of particles of $1.2 \mathrm{~mm}$.

\subsubsection{The Mixing}

The amount of water added to the clay is determined based on the measured moisture of the raw material, the manufacturing process and the type of product. The three samples TK1.1, TK1.2, and TK1.4, mixed in equal portions, are placed in the mixer and then water is added gradually until a homogeneous mixture is obtained. For a clay mass of $8 \mathrm{~kg}$, the quantity of water added is $0.82 \mathrm{~kg}$, and it corresponds to moisture of $18.8 \%$.

\subsubsection{The Extrusion}

The clay is extruded using a molding machine. Depending on the type of the desired product (type of brick), the output head of the molding machine can be modified. A result of brick extrusion is shown in Figure 11. The extrusion was carried at $10 \mathrm{MPa}$ and a vacuum pump deaerated the blend [7].

The extruded material shows a soft paste of clay with a good plasticity and a hardness of $1.5\left(<2 \mathrm{~kg} \cdot \mathrm{cm}^{-2}\right)$.

\subsubsection{The Drying of the Bricks}

The drying of clay paste is an important and delicate industrial process, both because of its cost price but also because it is the source of many defects such as deformations and cracks which quickly increase the rate of thrown-out bricks. The drying of clays involves various physical phenomena, some of which are well known, such as dimensional variation. 


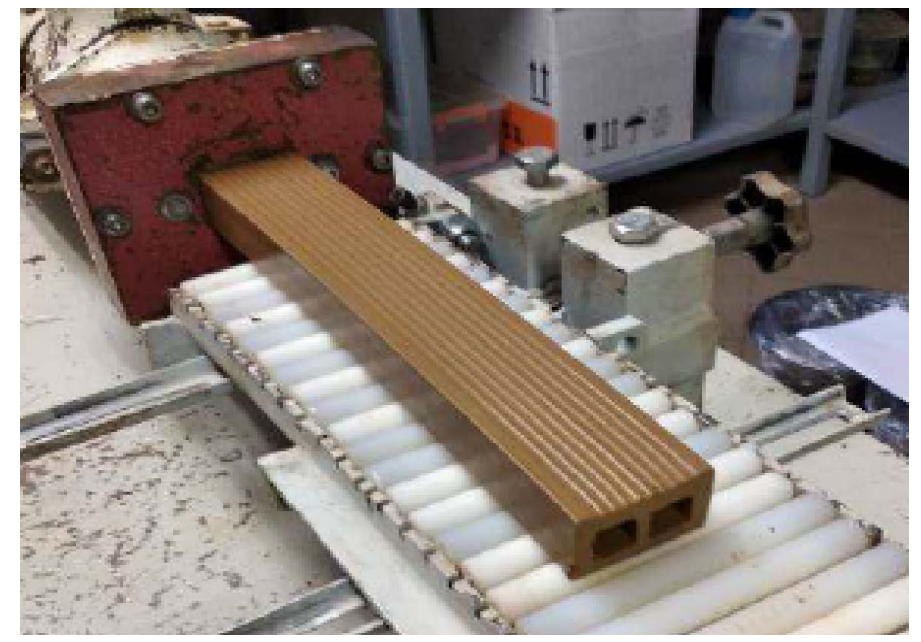

Figure 11. Bricks extrusion.

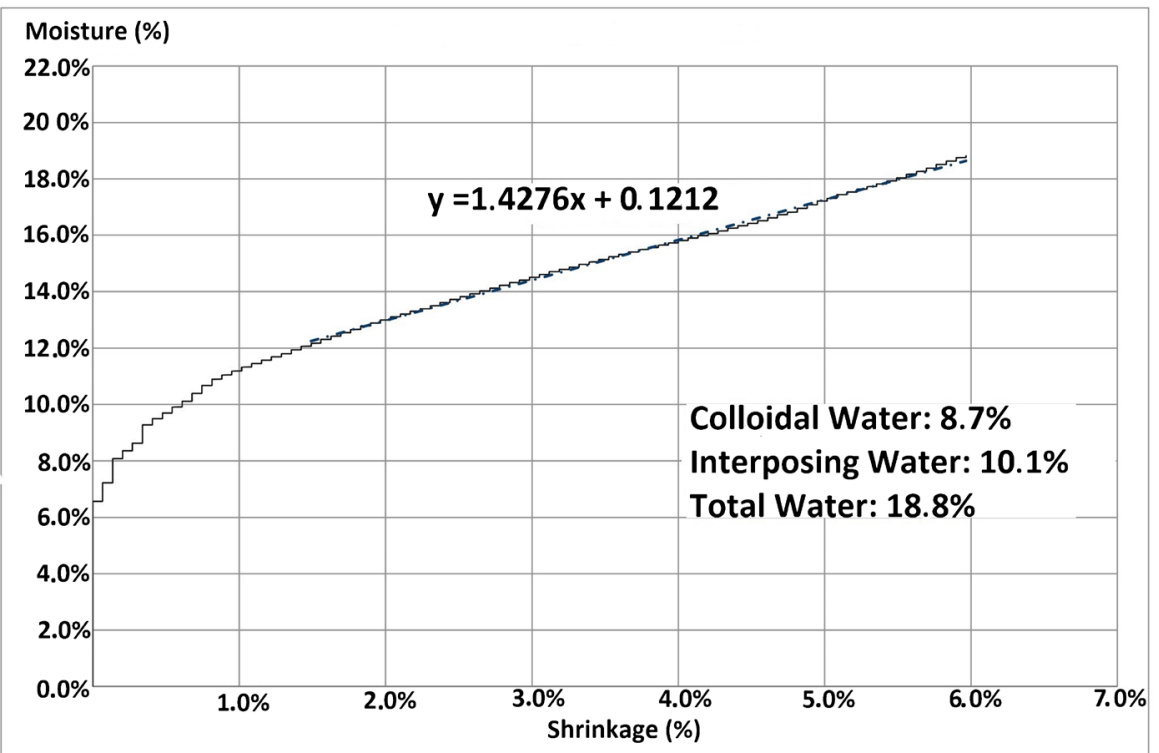

Figure 12. Bigot's curve of the Thicky clay mixture.

The dimensional variations of clay paste during drying are well known. They are most often represented in the form of a Bigot curve (Figure 12). This curve allows the linear shrinkage to be predicted as a function of the evaporated water. Firing shrinkage is calculated as a relative change in the length of the wet shaped bricks after the firing process.

The results obtained are summarized in Table 2 . The clay requires an average quantity of water to obtain a plastic paste which shrinks when drying with moderate length of shrinkage. Its classic Bigot's curve has a linear part with an average slope and a short transition phase. These characteristics indicate a good drying behavior. After three (3) hours of drying, for a gradual and maximum temperature of $75^{\circ} \mathrm{C}$, the measured moisture drops from $80 \%$ to $05 \%$ (Figure 13 and Figure 14). The residual moisture of the briquettes measured is $2.8 \%$. There is no apparent deterioration after a drying period of 3 hours. 
Table 2. Values obtained according to the Bigot's curve of the clay mixture.

\begin{tabular}{cc}
\hline Mixture TK1.1, TK1.2, and TK1.4 & Values obtained \\
\hline Colloidal water (in\% of dry mass) & 8.7 \\
Interposition water (in\% of dry mass) & 10.1 \\
Preparation water (in\% of dry mass) & 1.8 \\
Drying shrinkage (\% of dry length) & 6.0 \\
Slope of the linear part & 1.43 \\
\hline
\end{tabular}

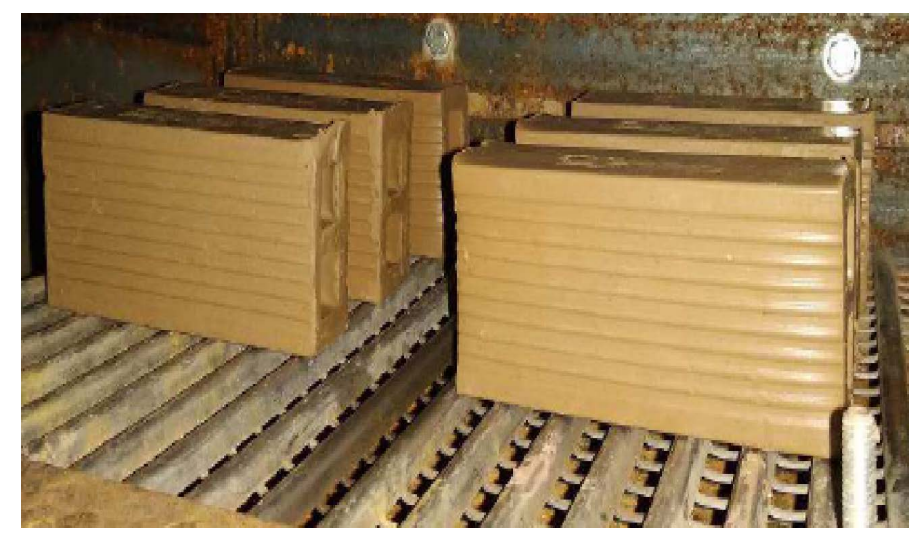

Figure 13. Samples before drying.

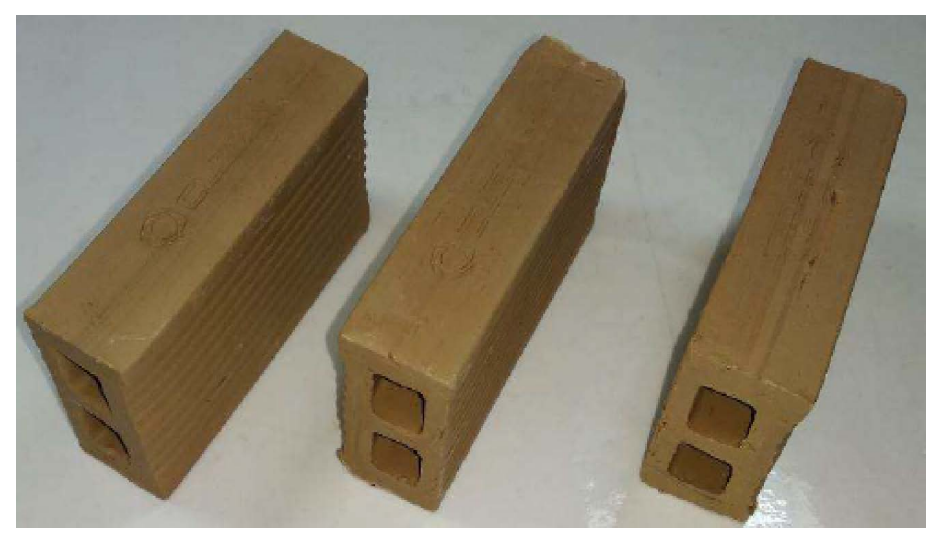

Figure 14. Samples after drying.

\subsubsection{Bricks Firing}

In the firing tests, a standard firing cycle has been proposed in order to predetermine the most suitable firing temperature for industrial production. Several cycles of temperature varying between $900^{\circ} \mathrm{C}$ and $1100^{\circ} \mathrm{C}$ were carried out. A 24-hour cycle with a gradual temperature up to $950^{\circ} \mathrm{C}$ with a plateau of 2 hours and 30 minutes was used. The firing process was developed in a programmable laboratory furnace and the firing curve was set as shown in Figure 15. Arsenovic et al. [8] showed that firing temperature is the most influential variable for mechanical characteristics predictions.

Study conducted by Charai et al. [9] shows that the bricks were dried in a dryer room at $60^{\circ} \mathrm{C}$ for three days to prevent shrinkage cracks, and fired in a 
furnace for $24 \mathrm{~h}$ at selected temperature of $880^{\circ} \mathrm{C}$.

No firing defect was observed and the bricks do not show any cracks, deformations, or efflorescence with an orange-red color. The firing shrinkage gives a value of $0.8 \%$ for a 24 hours' absorption of $8.5 \%$. Figure 16 and Figure 17 give an overview of the samples of bricks before and after firing at the temperature of $950^{\circ} \mathrm{C}$

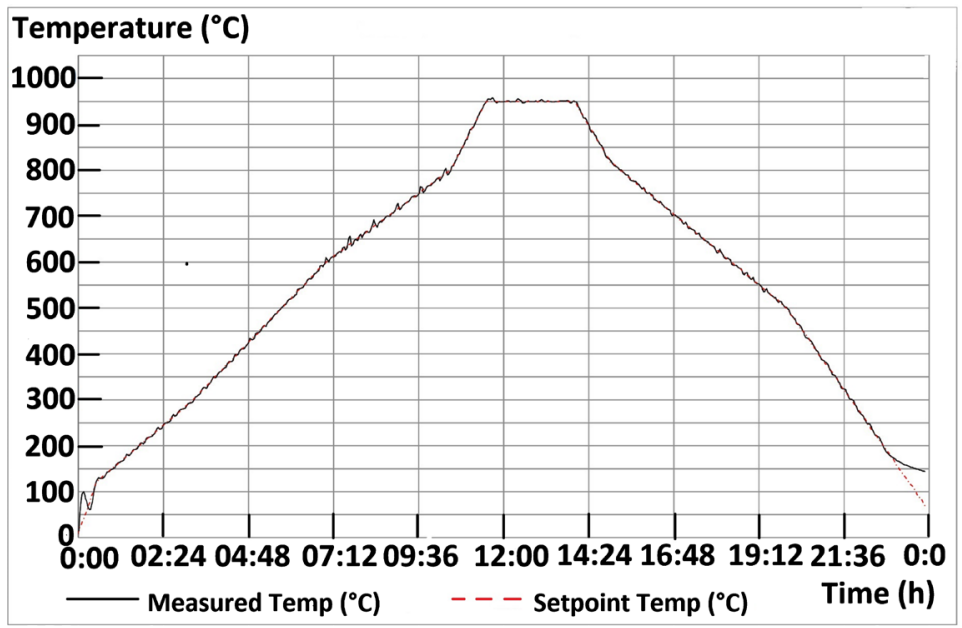

Figure 15. Curve of the 24-hour firing test with a plateau of 2 hours and 30 minutes at $950^{\circ} \mathrm{C}$.

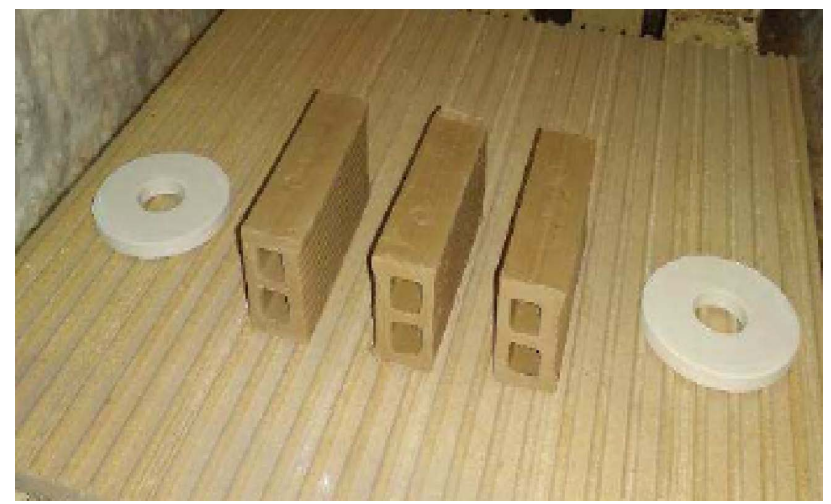

Figure 16. Samples of bricks before firing.

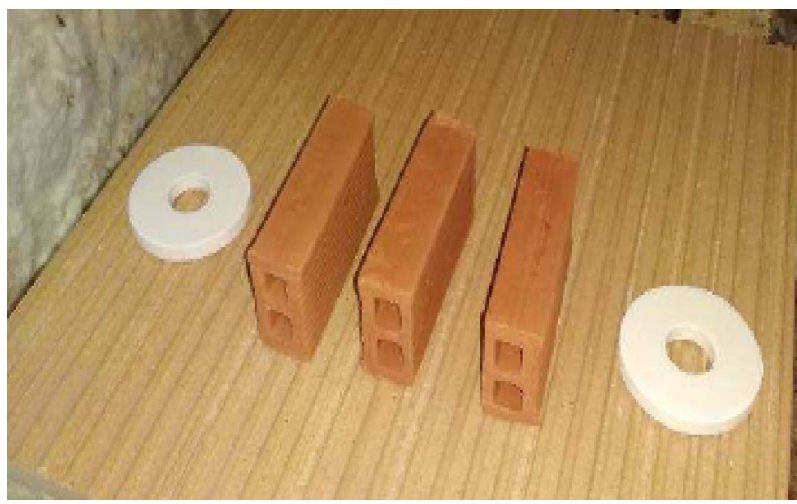

Figure 17. Samples of bricks after firing at $950^{\circ} \mathrm{C}$. 


\subsubsection{Control of Ceramic Behavior}

This involves the physical characteristics determination of the bricks including moisture, total shrinkage, density, loss on ignition and water absorption. At the end of the ceramic behavior tests mentioned above, the results obtained are recorded in Table 3.

The mixing in an equal part of the three samples TK1.1, TK1.2, and TK1.4 collected in the Thicky area requires an average quantity of preparation water to be extruded into a soft paste with good plasticity.

A 3-hour programmed drying test allows thin-walled with two-cell bricks to be dried without any deterioration appearing. The residual brick moisture reaches 3\% (dry). Thus, an accelerated drying of products in industrial condition is possible.

On the other hand, a drying test programmed in 6 hours makes it possible to dry the samples without any deterioration appearing. In this case, the residual brick moisture reaches $6.9 \%$ (dry).

After firing, bricks of beautiful appearance and smooth texture with an orangered color are obtained. The sound of the bricks shards suggests a good mechanical strength.

Ultimately, the bricks are characterized by a low loss on ignition, a low shrinkage value less than $1 \%$ (dry) and an acceptable water absorption value.

\section{Technical and Economic Optimization of the Clay Bricks Produced}

\subsection{Theoretical Formulas and Testing Procedure}

A technical and financial optimization of the production of fired clay bricks to ensure good physical and mechanical characteristics, on the clay quarry of SOFAMAC Company in Thicky was carried out. The lithology of the quarry cut front (Figure 18) shows plastic yellow clays, of smaller thickness $(\sim 1.8 \mathrm{~m})$ on top of the gray clays $(\sim 10 \mathrm{~m})$. The clay layers are all covered by a lateritic formation.

The yellow clays were used as a degreaser by mixing them with the gray clays, which has a greater thickness.

Mixtures (by mass) M1, M2, M3, M4, M5, and M6 with 10\%, 20\%, 30\%, 40\%, $50 \%$ and $60 \%$ of yellow clays and $90 \%, 80 \%, 70 \%, 60 \%, 50 \%$ and $40 \%$ gray clays

Table 3. Results of ceramic behavior tests on the bricks

\begin{tabular}{cccccc}
\hline $\begin{array}{c}\text { Bricks from mixture of } \\
\text { samples TK1.1+ TK1.2 } \\
\text { TK1.4 }\end{array}$ & $\begin{array}{c}\text { Extrusion } \\
\text { moisture }\end{array}$ & $\begin{array}{c}\text { Residual } \\
\text { moisture (\%) }\end{array}$ & $\begin{array}{c}\text { Shrinkage } \\
(\%)\end{array}$ & $\begin{array}{c}\text { Loss on } \\
\text { ignition (\%) }\end{array}$ & $\begin{array}{c}\text { Water } \\
\text { absorption } \\
(\%)\end{array}$ \\
\hline $\begin{array}{c}\text { Green color } \\
\text { hours drying of briquettes }\end{array}$ & 18.8 & & & & \\
6 hours drying of briquettes & 2.8 & & & \\
Firing at $950^{\circ} \mathrm{C}$ & 6.9 & 5.8 & & 8.5 \\
Firing at $900^{\circ} \mathrm{C}$ & & 0.8 & 4.4 & 9.4 \\
\hline
\end{tabular}




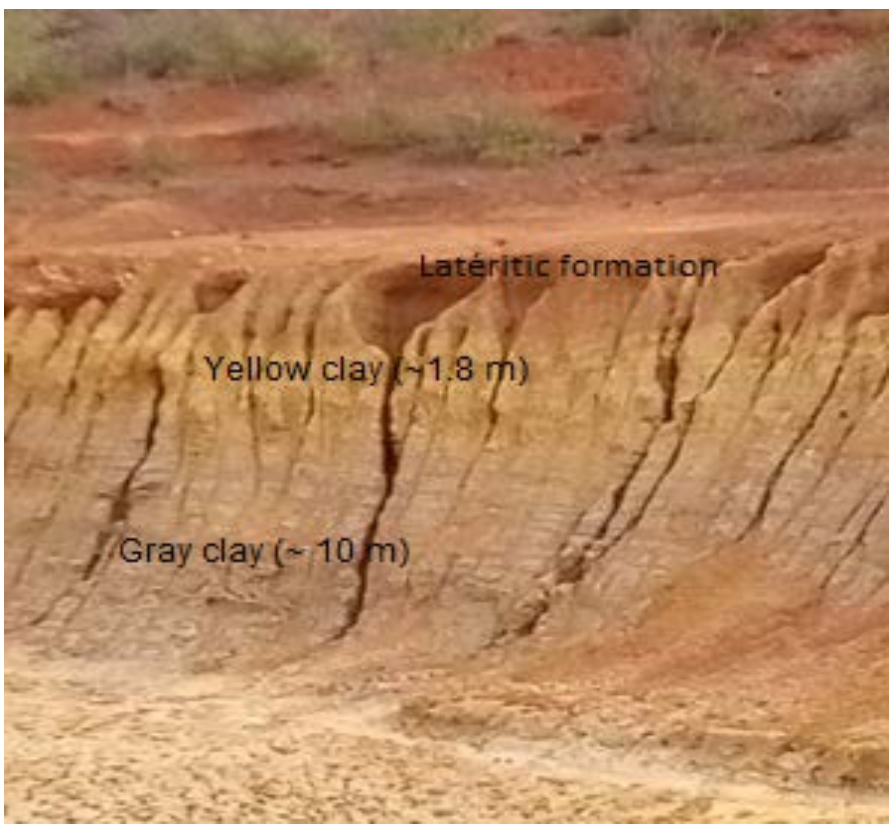

Figure 18. Lithology of the quarry cut front.

respectively have been used to assess the duration and the temperature of firing, while producing bricks that meet the physical and mechanical characteristics desired for their use in building works.

\subsubsection{Characterization of the Clays}

The tests on the raw material are very important because they allow the clay identification and the prediction of their behavior during shaping, drying, firing, and cooling processes but also of the bricks produced. Samples collected from the plant's stock were subjected to different types of tests.

\subsubsection{Natural Water Content of Clays}

The determination of the water content by mass is carried out according to standard NF P 94-050 [10]. Samples are placed in an oven at $105^{\circ} \mathrm{C}$ for 24 hours and their mass is determined, by weighing the samples before and after.

\subsubsection{Density of Clays}

The tests were carried out according to standard NF P 94-054 [11].

\subsubsection{Particle Size Analysis}

They were carried out according to standards NF EN ISO 17892-4 [12]. Particle size analyses are carried out by the wet sieving method and by hydrometer analysis. The grain size curves are given in Figure 19 shows two samples with mainly fine soils.

\subsubsection{Atterberg Limits}

Yellow and gray clays as well as mixtures are in the plastic domain according to standard NF EN ISO 17892-12 [13]. The Atterberg limits are the water contents of the soil at the considered transition state. The limits of liquidity $\left(\omega_{L}\right)$ and plas- 
ticity $\left(\omega_{P}\right)$ are determined, and the plasticity index $\left(I_{p}\right)$ which characterizes the plasticity of the clay is deducted from the difference between $\omega_{L}$ and $\omega_{P}$. The plasticity index is the range of moisture contents over which the soil deforms plastically.

The consistency index $\left(I_{C}\right)$ characterizes, considering the water content, the natural state of a soil compared to the Atterberg limits. It indicates the consistency (firmness) of a soil.

\subsubsection{Determination of the Lime Content}

A high level of limestone content in the clays leads to cracking during the drying and firing stages. The limestone content should not exceed 15\% of the mass of the clay mixture according to the various experimental methods. The calcium carbonate $\left(\mathrm{CaCO}_{3}\right)$ content was determined according to the standard NF P94-048 [14], using the Dietrich-Frühling calcimeter. The reaction of limestone sample with hydrochloric acid is given by Equation (1):

$$
\mathrm{CaCO}_{3}+2 \mathrm{HCl} \rightarrow \mathrm{CaCl}_{2}+\mathrm{H}_{2} \mathrm{O}+\mathrm{CO}_{2}
$$

\subsubsection{Methylene Blue Test and Activity of Clays}

The methylene blue test was carried out according to standard NF P94-068 [15]. The activity of clays is the ratio between the methylene blue value determined according to standard by NF EN ISO 17892-4 [12] and the particles content of dimensions smaller than $2 \mu \mathrm{m}$.

\subsection{Manufacturing Process of Clay Bricks}

The manufacturing process of clay bricks by SOFAMAC Company consists in different but independent successive stages. Standard NF P 13-301 [16] sets the physical criteria and aspects which allow the validation of fired clay bricks manufactured industrially for construction.

\subsubsection{Water Absorption}

The objective is to determine the quantity of water at room temperature absorbed by the bricks (Figure 20) and measured according to standard NF EN 771-1 + A1/CN [17]. The water absorption capacity is one of the important criteria for representing the quality and strength of the clay bricks.

\subsubsection{Capillarity Absorption of the Bricks}

Measuring the capillarity absorption of water of a brick consists of placing a brick, with a mark made at $10 \mathrm{~mm}$ from its bottom, following its setup direction in a container filled with water. The brick is left in the container for a period time of 60 minutes (1 hour) as specified by the standard NF EN 772-11 (F) [18].

\subsubsection{Loss on Ignition}

The Loss On Ignition (LOI) refers to the quantity of material lost by the brick during its firing. In fact, the firing process leads to a reduction in mass of the brick due to residual water evaporation after the bricks drying, to the organic 
volatile compounds release, and other components whose volatilization temperature is lower than the bricks firing temperature.

\subsection{Mechanical Tests}

Compressive strength test, which is an essential and frequently determined parameter to assess the ability of a material to be used in construction, were conducted on the bricks.

The compressive strength given by Equation (2) is determined according to the standard NF EN 772-1 [19].

$$
R c=\frac{F}{s}
$$

$R c$ is the compressive strength value in $\mathrm{N} \cdot \mathrm{mm}^{-2}, F$ is the compressive breaking load in $\mathrm{N}$, and $s$ is the contact section of the brick $\left(\mathrm{mm}^{2}\right)$.

\subsection{Thermal Characterization of Bricks}

For this characterization, a measuring device of an asymmetric hot plane type, using the measurement of the temperature of the heated face of the sample, was carried out at the Applied Energetic Laboratory (LEA) of Ecole Supérieure Polytechnique of Dakar. The heat transfusion is unidirectional and vertical to the sample. The measuring device is connected to an electronic acquisition unit and software of a graphical interface type makes it possible to control the tests and process the results.

The thermal resistance is obtained by Equation (3):

$$
R=\frac{e}{\lambda}
$$

From Equation (3), the Lambda coefficient is determined if we know the thermal resistance and the thickness, and vice versa. The thermal resistance of a building component made up of several superimposed layers, and perpendicular to the heat flow, is the sum of the individual thermal resistances of all the layers (Equation (4)):

$$
R=\sum R_{i}
$$

\section{Testing Results and Discussions}

The chemical studies, carried out on the clay collected from various stacked piles, gave the results shown in Table 4 .

Table 4 shows that Thicky clays contain three main chemical elements which are $\mathrm{SiO}_{2}, \mathrm{Al}_{2} \mathrm{O}_{3}$, and $\mathrm{Fe}_{2} \mathrm{O}_{3}$. The other chemical elements identified have varying contents that do not exceed $2 \%$ with water content at around 5\%. According to the analysis carried out, $\mathrm{SiO}_{2}$ being unbound to $\mathrm{Al}_{2} \mathrm{O}_{3}$ decreases the binding power of clays, increases the porosity of the bricks once fired and lowers their solidity.

Alumina is an element which strengthens the plasticity of clay, and gives a mechanically resistant product. It also allows the products to withstand high 
temperatures. To have good fired products quality, the alumina content must vary between 10 and $30 \%$ what we have with Thicky clay. In contrast, $\mathrm{CaO}$ causes cracking in raw products exposed to air. Excess of $\mathrm{CaO}$ can cause swelling during firing and bricks breaking.

The dark red color reflects a higher $\mathrm{Fe}_{2} \mathrm{O}_{3}$ and $\mathrm{MgO}$ content in the clay, but a large amount of iron lowers its refractoriness.

$\mathrm{Na}_{2} \mathrm{O}$ and $\mathrm{K}_{2} \mathrm{O}$ lower the sintering temperature of the clay. The sintering constitutes the whole process of shrinkage, density and resistance increases of clays during the firing process.

Table 5 gives the water content of the two types of clays. An average of 5.45\% is obtained.

The obtained results of the density tests are shown in Table 6. They show that the gray colored clays are less dense than the yellow colored ones.

The particle size curve show that the gray clays are less coarse than the yellow clays. Gray clays and yellow clays contain a fairly large amount of fine particles, of about $95 \%$ of the total mass.

According to the distribution of the granular fractions, the results obtained

Table 4. Results of chemical analysis obtained on the clays.

\begin{tabular}{ccc}
\hline \multirow{2}{*}{ Chemical elements } & Grey clays & Yellow clays \\
\cline { 2 - 3 } & \multicolumn{2}{c}{ Chemical composition (\%) } \\
\hline $\mathrm{SiO}_{2}$ & 76.833 & 72.394 \\
$\mathrm{Al}_{2} \mathrm{O}_{3}$ & 12.552 & 12.270 \\
$\mathrm{Fe}_{2} \mathrm{O}_{3}$ & 2.619 & 4.930 \\
$\mathrm{TiO}_{2}$ & 1.042 & 0.973 \\
$\mathrm{CaO}$ & 0.235 & 0.253 \\
$\mathrm{MgO}$ & 0.875 & 0.750 \\
$\mathrm{~K} 2 \mathrm{O}$ & 1.560 & 1.470 \\
$\mathrm{Na}_{2} \mathrm{O}$ & 0.495 & 0.820 \\
$\mathrm{H}_{2} \mathrm{O}$ or loss on ignition & 4.225 & 4.980 \\
\hline
\end{tabular}

Table 5. Results of natural water content of the clays.

\begin{tabular}{cc}
\hline Types of clays & Water content $(\omega \%)$ \\
\hline Grey clays & $5.09 \%$ \\
Yellow clays & $5.82 \%$ \\
\hline
\end{tabular}

Table 6. Density of clays.

\begin{tabular}{lccc}
\hline & Grey clays & Yellow clays \\
\hline$\rho\left(\mathrm{g} \cdot \mathrm{cm}^{-3}\right)$ & Bulk & 1.39 & 1.42 \\
& Specific & 2.25 & 2.51 \\
\hline
\end{tabular}


indicate that these clays consist mainly of $5 \%$ of clay fraction, $9 \%$ of fine silt, $22 \%$ of medium silts, $60 \%$ of coarse silts, and $4 \%$ of sand.

A slight variation was observed in particle size between the two types of clays (Figure 19).

The Atterberg limits results obtained on gray clays and yellow clays as well as on the mixtures between the two clays are presented in Table 7.

The plasticity index values vary between $20 \%$ and $40 \%$. However, the yellow clays are less plastic than the gray ones. This plasticity decreases as the mass of the yellow clay increases in the mixture. This fact allows the yellow clays to be used as a degreaser in the mixture.

The plotting of the different values of Ip and $\omega L$ in Casagrande diagram [20] shows that the gray clays are considered as very plastic inorganic clays and the yellow clays as moderately plastic inorganic clays. However, their mixtures at the proportions by mass indicated in Table 9 lie between the two types of behavior.

The limestone content values found on gray clays and yellow clays as well as in the mixtures are presented in Table 8.

The different types of clays analyzed are classified as non-calcareous materials,

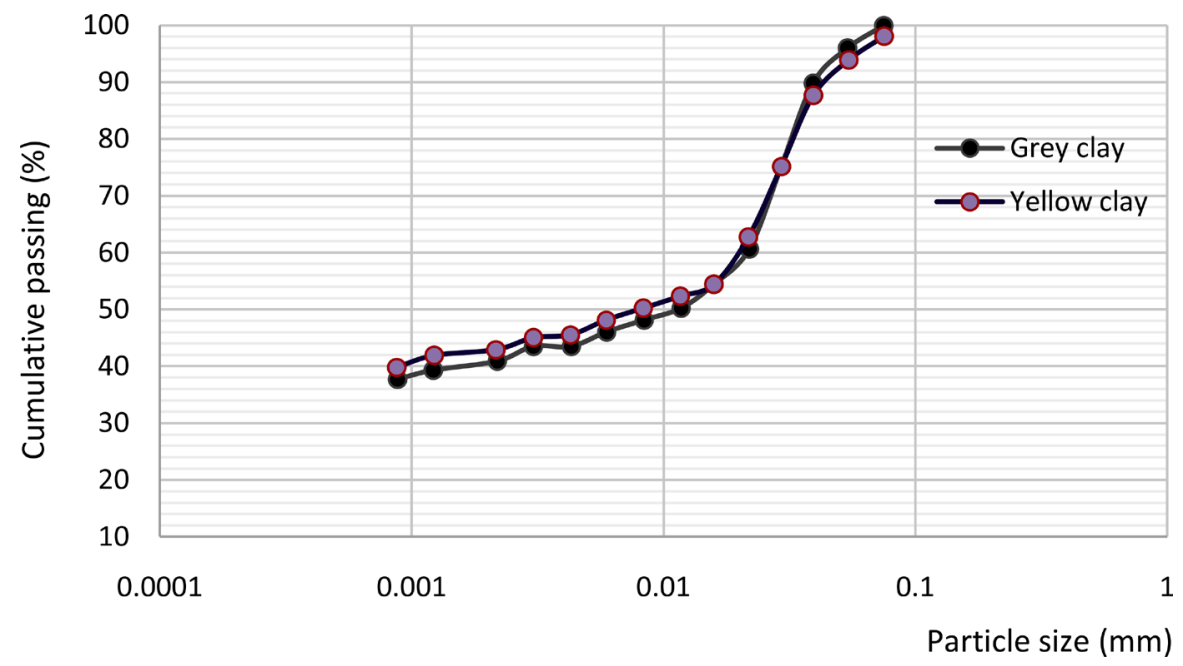

Figure 19. Curves of the hydrometer analysis of the two types of clays.

Table 7. Results of plasticity test on the clay and on the mixtures ( $\mathrm{YC}=$ Yellow clays, GC $=$ Grey clays).

\begin{tabular}{|c|c|c|c|c|c|c|c|}
\hline & Mixture & & $\mathbf{M}_{1}$ & $\mathbf{M}_{2}$ & $\mathrm{M}_{3}$ & $\mathrm{M}_{4}$ & $\mathrm{M}_{5}$ \\
\hline & $100 \% \mathrm{YC}$ & $100 \%$ GC & $\begin{array}{c}10 \% \mathrm{YC} \\
+ \\
90 \mathrm{GC}\end{array}$ & $\begin{array}{c}20 \% \text { YC } \\
+ \\
80 \% \text { GC }\end{array}$ & $\begin{array}{c}30 \% \mathrm{YC} \\
+ \\
70 \mathrm{GC}\end{array}$ & $\begin{array}{c}40 \% \mathrm{YC} \\
+ \\
60 \% \mathrm{GC}\end{array}$ & $\begin{array}{c}50 \% \text { YC } \\
+ \\
50 \% \text { GC }\end{array}$ \\
\hline$\omega(\%)$ & 5.82 & 5.09 & & & & & \\
\hline$\omega_{L}(\%)$ & 39.2 & 58.1 & 57.7 & 54.79 & 58.33 & 51.49 & 45.3 \\
\hline$\omega_{P}(\%)$ & 14 & 20.11 & 16.78 & 15.81 & 20 & 17.01 & 16.9 \\
\hline $\mathrm{I}_{\mathrm{P}}$ & 25.2 & 37.99 & 40.92 & 38.98 & 38.33 & 34.48 & 28.4 \\
\hline $\mathrm{I}_{\mathrm{C}}$ & 1.30 & 1.39 & & & & & \\
\hline
\end{tabular}


Table 8. Results of limestone content obtained from the clays samples.

\begin{tabular}{ccc}
\hline Types of clay (\%) & $\mathrm{CaCO}_{3}(\%)$ & Classification \\
\hline $100 \%$ grey clay & 9.86 & \\
$100 \%$ yellow clay & 8.24 & \\
$90 \%$ grey clay $+10 \%$ yellow clay & 8.96 & Non calcareous \\
materials \\
$80 \%$ grey clay + $20 \%$ yellow clay & 8.6 & \\
$70 \%$ grey clay $+30 \%$ yellow clay & 9.68 & \\
$60 \%$ grey clay $+40 \%$ yellow clay & 9.65 & \\
$50 \%$ grey clay $+50 \%$ yellow clay & 9.59 & \\
\hline
\end{tabular}

Table 9. Blue methylene values and activity of clays.

\begin{tabular}{|c|c|c|c|c|c|c|c|}
\hline & & & $\mathbf{M}_{1}$ & $\mathbf{M}_{2}$ & $\mathrm{M}_{3}$ & $\mathrm{M}_{4}$ & $\mathrm{M}_{5}$ \\
\hline & $\begin{array}{c}100 \% \\
\mathrm{YC}\end{array}$ & $\begin{array}{c}100 \% \\
\text { GC }\end{array}$ & $\begin{array}{c}10 \% \mathrm{YC} \\
+ \\
90 \mathrm{GC}\end{array}$ & $\begin{array}{c}20 \% \text { YC } \\
+ \\
80 \% \text { GC }\end{array}$ & $\begin{array}{c}30 \% \mathrm{YC} \\
+ \\
70 \mathrm{GC}\end{array}$ & $\begin{array}{c}40 \% \mathrm{YC} \\
+ \\
60 \% \mathrm{GC}\end{array}$ & $\begin{array}{c}50 \% \text { YC } \\
+ \\
50 \% \text { GC }\end{array}$ \\
\hline $\begin{array}{l}\text { VBS ( } \mathrm{g} \text { for } 100 \mathrm{~g} \\
\text { of dry sample) }\end{array}$ & 4.0 & 6.0 & 5.5 & 4.83 & 4.17 & 3.83 & 3.33 \\
\hline Activity (A) & 0.095 & 0.15 & & & & & \\
\hline
\end{tabular}

since their calcium carbonate contents do not exceed $10 \%$. These results obtained constitute an advantage for the fired clay bricks production since a high content of limestone makes cracks appear on the final product.

The results obtained for the methylene blue and the grain size tests are given in Table 9. According to standard, the activity values obtained (A), only for the $100 \%$ of GC and $100 \%$ of YC, do not exceed 3. This shows that the clays tested are in the inactive range of clays.

The tests carried out suggest putting an emphasis on the grain size distribution of the clay, which has an influence on the stability of the structure. The values of Ip and $\omega L$ also allow us to classify materials by their plasticity and their consistency. Gray clay appeared to be more plastic than yellow clay, but they all have a hard consistency. The influence of grain size distribution is also evident on the kind of bricks obtained.

All the results obtained prompted the choice to produce fired clay bricks with a mixture of $50 \%$ of gray clay and $50 \%$ of yellow clay at a temperature of $950^{\circ} \mathrm{C}$ for six (6) hours. This choice allowed the company to use now in its process the yellow clays which had previously been deposited in favor of the gray clays which were overexploited.

For the bricks manufacturing, the physical criteria and aspects which allow the validation of fired clay bricks manufactured industrially for construction are summarized in Table 10.

The bricks produced with $50 \%$ of gray clay and $50 \%$ of yellow clay, fired at $950^{\circ} \mathrm{C}$ for 5 hours do not show any signs of bursting or any deformation observed. They present straight edges and uniform surfaces. The flexion measured 
between two parallel edges varies between 1 and 3 millimeters. The measured shrinkage values vary between $5.36 \%$ and $7.62 \%$. These results give very acceptable appearance characteristics for the products manufactured.

The results obtained for the water absorption values on the bricks studied are shown in Table 11. They were found smaller than the tolerance of $15 \%$ provided by standard NF P 13-301. This suggests a good water absorption behavior for the

Table 10. Main criteria to be verified according to the standard NF P 13-301.

\begin{tabular}{ccc}
\hline Characteristics & Specification/defects & Tolerances \\
\hline $\begin{array}{c}\text { Appearance } \\
\text { characteristics } \\
\text { Physical } \\
\text { characteristics }\end{array}$ & $\begin{array}{c}\text { Cracks - Deformation - Blistering - Tearing - } \\
\text { Flatness Edge straightness - Surface condition }\end{array}$ & $\begin{array}{c}\text { Visual criteria to be checked and } \\
\text { flexion not exceeding } 5 \mathrm{~mm}\end{array}$ \\
& Bursting & No white spot \\
Shrinkage & $<8 \%$ \\
& Water absorption & $<15 \%$ \\
& Loss on ignition & $<15 \%$ \\
\hline
\end{tabular}

Table 11. Water absorption values of the studied bricks.

\begin{tabular}{|c|c|c|c|}
\hline Bricks references & Initial mass $(\mathrm{kg})$ & $\begin{array}{c}\text { Mass after } 24 \mathrm{~h} \\
\text { of immersion }(\mathrm{kg})\end{array}$ & $\begin{array}{c}\text { Water absorption } \\
\text { values }(\%)\end{array}$ \\
\hline Amsa 1 & 5.940 & 6.350 & 6.9 \\
\hline Amsa 2 & 6.409 & 7.003 & 9.3 \\
\hline Amsa 1 bis & 2.969 & 3.239 & 9.1 \\
\hline Amsa 2 bis & 3.763 & 4.037 & 7.3 \\
\hline Amsa 3 & 1.630 & 1.764 & 8.2 \\
\hline Amsa 4 & 5.189 & 5.597 & 7.9 \\
\hline Amsa 4 bis & 6.396 & 6.956 & 8.8 \\
\hline Claustra A & 4.659 & 5.023 & 7.8 \\
\hline Claustra B & 4.319 & 4.699 & 8.8 \\
\hline Claustra C & 4.688 & 5.069 & 8.1 \\
\hline Claustra D & 3.769 & 4.069 & 8.0 \\
\hline BP 06 & 1.601 & 1.774 & 10.8 \\
\hline BP 60 & 3.081 & 3.366 & 9.3 \\
\hline BP 50 & 2.756 & 3.084 & 11.9 \\
\hline BP 200 & 9.360 & 10.113 & 8.0 \\
\hline BR 200 & 9.524 & 10.660 & 11.9 \\
\hline BR 10 & 3.813 & 4.199 & 10.1 \\
\hline BS $200-1$ & 9.294 & 10.077 & 8.4 \\
\hline BS 150 & 13.178 & 14.026 & 6.4 \\
\hline Hourdis & 7.076 & 7.685 & 8.6 \\
\hline
\end{tabular}


studied bricks. Figure 20 gives an example of a soaking brick in water.

A lower value of the water absorption capacity is always desired for good quality of clay bricks [21].

For the capillarity absorption of the bricks, as soon as this time has elapsed, the water raising by capillarity is measured from the marking line with a graduated ruler (Figure 21).

The capillarity absorption values obtained for the different types of fired clay bricks according to the standard are given in Table 12.

According to the results obtained on the 20 types of fired clay bricks produced by SOFAMAC, the capillarity absorption rates belong to the class of very poorly absorbent bricks according to standard NF EN 772-11.

The results of loss on ignition obtained after the bricks firing are shown in Table 13.

For the 20 types of bricks submitted to the test, the losses on ignition values are less than $10 \%$. Johari et al. [22] found a LOI of $8.75 \%$ for the clay for manufacturing fired clay brick mixed with waste rice husk ash.

The maximum values allowed for a good quality of brick according to the standards ASTM C618 (1980) [23] are respectively 10\% and 15\%. So the values obtained comply with the standards and remain acceptable in order to avoid a

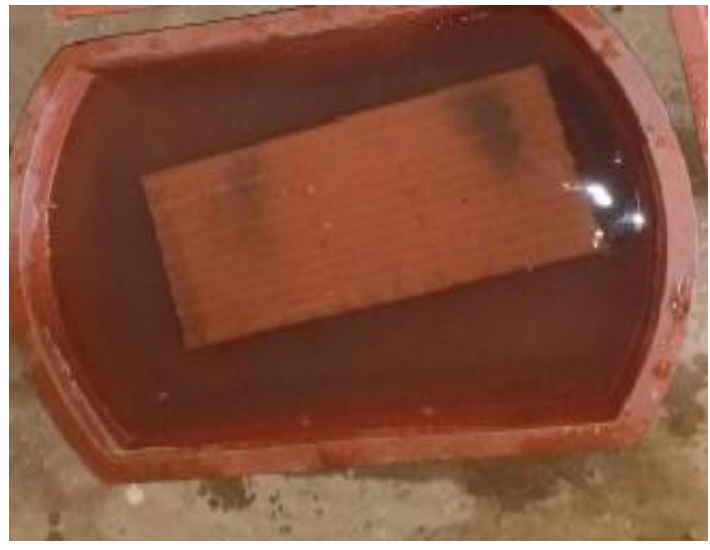

Figure 20. Submerged brick during an absorption test in a pan.
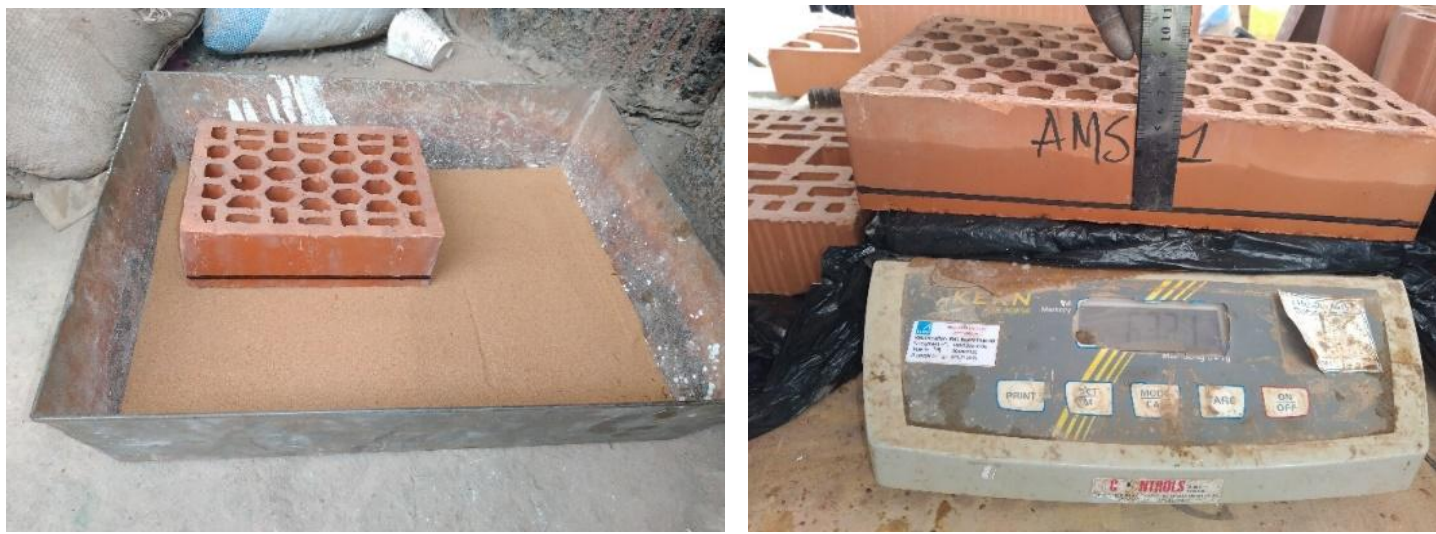

Figure 21. Brick subjected to the capillarity absorption test. 
height of the cells which is the same as the brick, the area occupied by the cells on the laying face would then be the ratio of the volume by the height of the bricks (Figure 22).

The results of brick measurements, failure loads, and compressive strength value are compiled in Table 14. The test is carried out using a classic concrete press, operating with a hydraulic pressure system which moves the lower part upwards until the brick breaks (Figure 23).

The compressive strength of the bricks mainly depends on the mineral structure, which strongly depends on the raw materials, drying and firing process (e.g. increasing/decreasing temperature rates, soaking time, and moisture content [24]. The sintering and mechanical properties of the clay brick samples depend on the optimum conditions maintained at the time of their manufacturing.

To meet the requirements of standards NF DTU 20.1 [25] and NF DTU 20.13 [26], the compressive strength average specifications are given according to the following rules:

- For fired clay bricks with horizontal perforations, the average compressive strength must be greater than or equal to $2.8 \mathrm{~N} \cdot \mathrm{mm}^{-2}$;

- For fired clay bricks with vertical perforations, the average compressive strength must be greater than or equal to $4 \mathrm{~N} \cdot \mathrm{mm}^{-2}$;

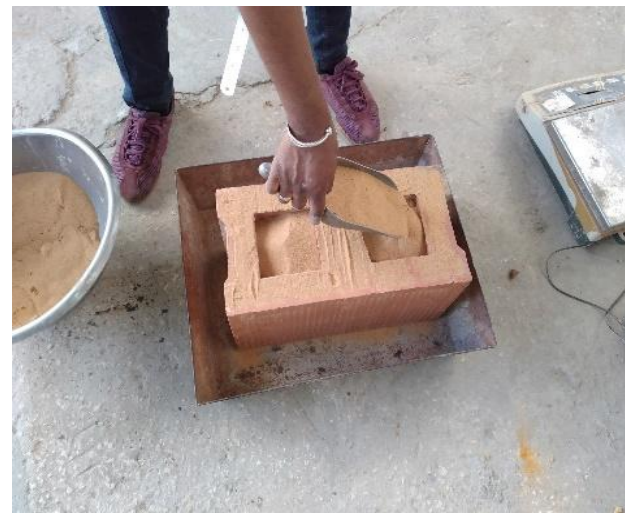

(a)

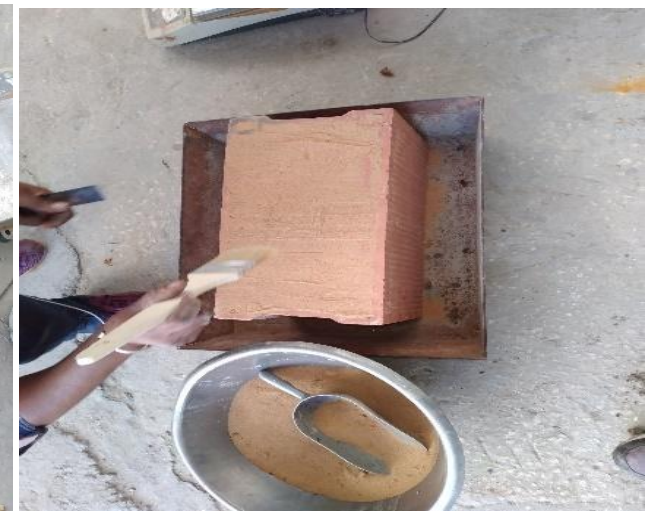

(b)

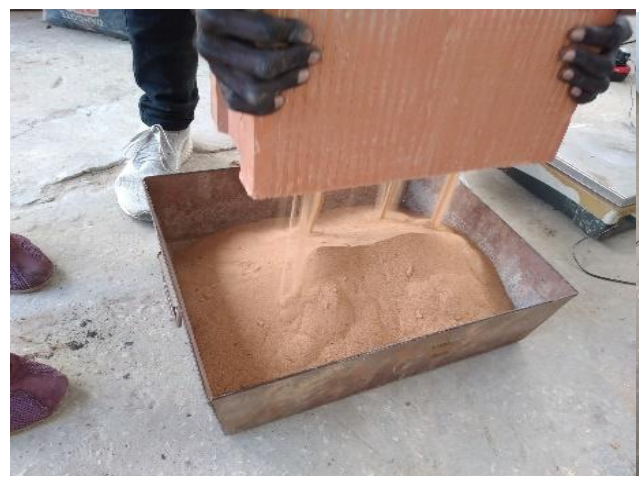

(c)

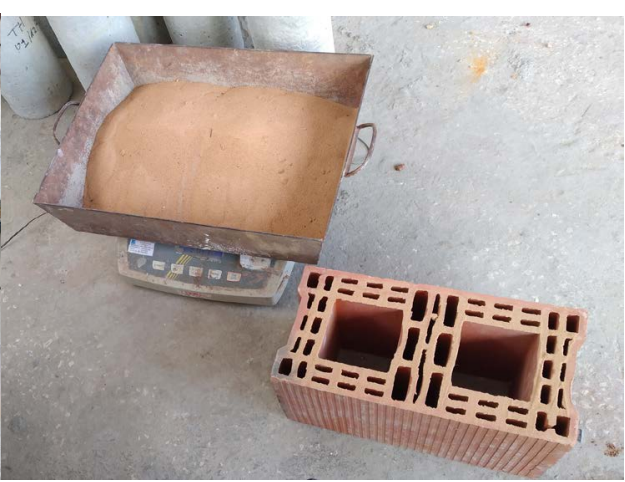

(d)

Figure 22. Illustration of the method used to determine the load application area of a brick with cells. (a) Filling of the brick cells with sand; (b) Sand level making; (c) Sand extraction; (d) Sand weighing. 
Table 14. Compilation of parameters during the compression tests.

\begin{tabular}{|c|c|c|c|c|}
\hline $\begin{array}{l}\text { Bricks } \\
\text { references }\end{array}$ & $\begin{array}{c}\text { Mass of } \\
\text { brick (kg) }\end{array}$ & $\begin{array}{l}\text { Effective section } \\
\qquad\left(\mathrm{cm}^{2}\right)\end{array}$ & $\begin{array}{l}\text { Failure load } \\
\qquad(\mathrm{kN})\end{array}$ & $\begin{array}{l}\text { Compressive strength } \\
\text { value }(\mathrm{MPa})\end{array}$ \\
\hline Amsa 1 & 6 & 853 & 365 & 4.3 \\
\hline Amsa 1 bis & 3 & 410 & 200 & 4.9 \\
\hline Amsa 2 bis & 3.8 & 367 & 159.8 & 4.4 \\
\hline Amsa 2 & 6.3 & 853 & 382 & 4.5 \\
\hline Amsa 3 & 1.6 & 254 & 172 & 6.8 \\
\hline Amsa 4 & 5.1 & 196 & 71 & 3.7 \\
\hline Amsa 4 bis & 6.3 & 330 & 93 & 2.8 \\
\hline Claustra A & 4.5 & 561 & 75 & 1.3 \\
\hline Claustra B & 4.5 & 561 & 68.4 & 1.2 \\
\hline Claustra C & 4.3 & 199 & 47 & 2.3 \\
\hline Claustra D & 4.7 & 199 & 71 & 3.5 \\
\hline Claustra E & 3.7 & 191 & 42 & 2.2 \\
\hline BR200 & 9.5 & 580 & 165.5 & 2.9 \\
\hline BP200 & 9 & 551 & 310 & 5.6 \\
\hline BP50 & 2.88 & 368 & 275 & 7.5 \\
\hline BP60 & 2.95 & 400 & 210 & 5.2 \\
\hline BS 150 & 13.4 & 807 & 345 & 4.3 \\
\hline BР06 & 1.5 & 163 & 165 & 10.1 \\
\hline BR10 & 3.9 & 128 & 92.5 & 7.2 \\
\hline BS200-1 & 9.3 & 650 & 310 & 4.7 \\
\hline
\end{tabular}

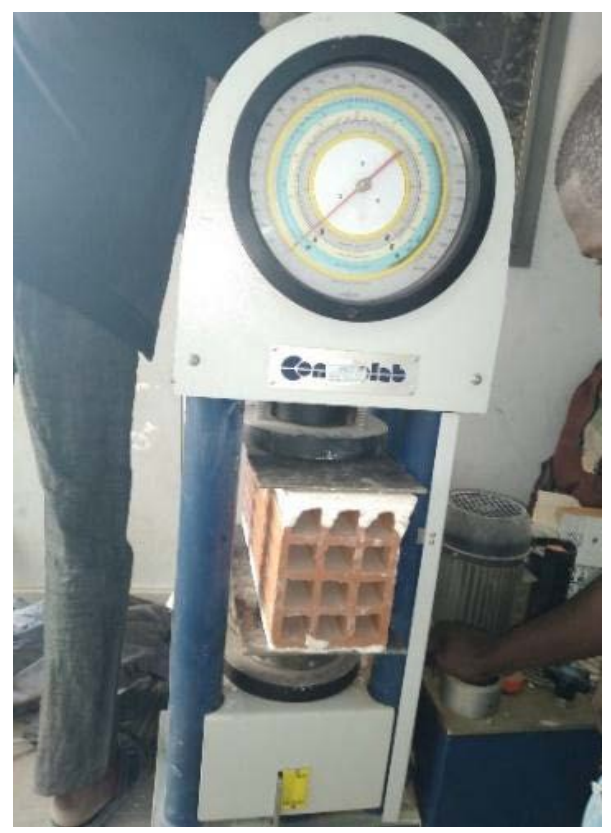

Figure 23. Press used for the determination of compressive strength. 
- For other bricks, the average compressive strength must be greater than or equal to $10 \mathrm{~N} \cdot \mathrm{mm}^{-2}$.

According to the requirements of these standards, all the bricks with horizontal perforations tested (Amsa 4, Amsa 4 bis and BR200) show satisfactory results.

Bricks with vertical perforations have satisfactory results and are much better than bricks with horizontal perforations. This is due to the fact that the axial stresses applied on bricks with vertical perforations are absorbed over their entire height from the total area of the network of partitions forming the bricks cells, while for bricks with horizontal perforations, the stress is applied along a surface with a large void below.

The thermal characterization of bricks method allows the thermal conductivity and the thermal effusivity of the material to be determined in a short time (Figure 24).

Knowing the conductivity of the material which is $0.427 \mathrm{~W} \cdot \mathrm{m}^{-1} \cdot \mathrm{K}^{-1}$ and that of unventilated air which is $0.024 \mathrm{~W} \cdot \mathrm{m}^{-1} \cdot \mathrm{K}^{-1}$, it's possible to determine both the conductivity and the resistivity of the cellular wall brick. For illustration, we have chosen two types of bricks (BR200 and BS200) and the results are shown in Table 15 .

In comparison with the usual bricks made in cement in Senegal whose thermal conductivity values vary between 0.47 and $1.2 \mathrm{~W} \cdot \mathrm{m}^{-1} \cdot \mathrm{K}^{-1}$, the use of fired clay bricks for construction present more satisfactory results and must be favored for better sustainable development.

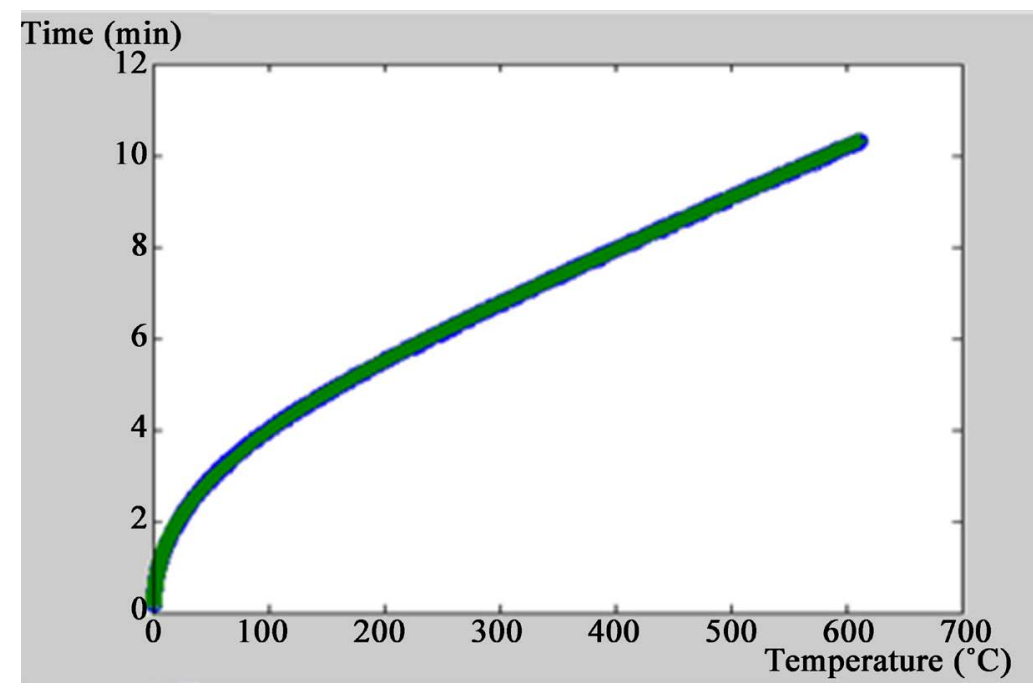

Figure 24. Thermal conductivity curve.

Table 15. Examples of thermal parameters acquired in some types of bricks.

\begin{tabular}{cccc}
\hline Bricks references & $\begin{array}{c}\text { Length and thickness } \\
(\mathrm{mm})\end{array}$ & $\begin{array}{c}\text { Conductivity } \\
\left(\mathrm{W} \cdot \mathrm{m}^{-1} \cdot \mathrm{K}^{-1}\right)\end{array}$ & $\begin{array}{c}\text { Resistivity } \\
\left(\mathrm{m}^{2} \cdot \mathrm{K}^{-\mathrm{W}^{-1}}\right)\end{array}$ \\
\hline Filling bricks: BR200 & $400 \times 145$ & 0.182 & 0.798 \\
Structure bricks: BS200 & $300 \times 145$ & 0.349 & 0.415 \\
\hline
\end{tabular}




\section{Conclusions}

In light of the various fieldwork and laboratory tests carried out, the area of Thicky has great potential for gray clays and yellow clays. Geophysical surveys and geotechnical tests carried out on the area have shown that the clay formations locally change to sandy clays or even clayey sands. However, these sandyclay formations can locally include clay but most often at great depth, more than $10 \mathrm{~m}$ below the surface.

Chemical analyses of the clay materials show that they contain mainly $\mathrm{SiO}_{2}$, $\mathrm{Al}_{2} \mathrm{O}_{3}$, and $\mathrm{Fe}_{2} \mathrm{O}_{3}$.

The grain size distribution shows a composition of $5 \%$ of clays, $9 \%$ of fine silts, $22 \%$ of medium silts, $60 \%$ of coarse silts, and $4 \%$ of sands. The gray clays show slight variations compared to the yellow ones with natural content of water of 5.09 and $5.82 \%$ respectively. The plasticity index varies between $24 \%$ and $30 \%$ with a low level of limestone.

The shrinkages measured on the manufactured bricks vary between $5.36 \%$ and $7.62 \%$ for water absorption between $6.4 \%$ and $11.9 \%$. The capillarity absorption of water oscillates between $0.01 \%$ and $0.12 \%$ and the loss on ignition values varying between $7.02 \%$ and $10 \%$. The compression tests on the bricks give satisfactory results depending on the type of brick tested.

In terms of thermal behavior, the tests performed on the fired clay brick give a thermal conductivity and effusivity of $0.42 \mathrm{~W} \cdot \mathrm{m}^{-1} \cdot \mathrm{K}^{-1}$ and $746.47 \mathrm{~J} \cdot \mathrm{K}^{-1} \cdot \mathrm{m}^{-2} \cdot \mathrm{s}^{-1 / 2}$ respectively.

The quality of clays used in the brick industry varies due to chemical, mineralogical, grain size and technological properties. The diversity of compositions and the heterogeneous nature of raw materials cause variations in fired product characteristics. The results obtained in this study show that the fired clay brick industry has been highlighted as an optimal sector for developing new materials in order to minimize environmental impact and improve building insulation envelopes.

\section{Acknowledgments}

This research project was supported by SFTP MINING SN Sarl (Société de Forage et de Travaux Publics), and SOFAMAC (Société de Fabrication des Matériaux de Construction).

\section{Conflicts of Interest}

On behalf of all authors, the corresponding author states that there is no conflict of interest.

\section{References}

[1] Agence Nationale de la Statistique et de le Démographie (ANSD) (2018) Rapport Agence Nationale de la Statistique et de le Démographie.

[2] Dominguez, D., Muñoz, P. and Muñoz, L. (2017) Impact of Using Lightweight Eco- 
Bricks as Enclosures for Individual Houses of One Story on Zones of High Seismicity. Materiales de Construcción, 67, e133. https://doi.org/10.3989/mc.2017.03316

[3] Eurostat (2012) Europe in Figures. Eurostat Yearbook 2012. https://ec.europa.eu/eurostat/documents/3217494/5760825/KS-CD-12-001-EN.PDF 1032ab046-5604-42cf-b0a5-7e63e1cda8bb

[4] Bellion, Y. and Guiraud, R. (1984) Le bassin sédimentaire du Sénégal. Synthèses des connaissances actuelles. In: Bureau des Recherches Géologiques et Minières (BRGM) et Direction des Mines et de la Géologie (DMG), Plan minéral de la république du Sénégal, Dakar, 4-63.

[5] Roger, J., Banton, O., Barusseau, J.P., Castaigne, P., Comte, J.-C., Duvail, C., Nehlig, P., Noël, B.J., Serrano, O. and Travi, Y. (2009) Notice explicative de la cartographie multi-couches à $1 / 50000$ et $1 / 20000$ de la zone d'activité du Cap-Vert. Ministère des Mines, de l'Industrie et des PME, Direction des Mines et de la Géologie, Dakar, $245 \mathrm{p}$.

[6] Barrusso, J.P., Roger, J., Dabo, B., Diagne, E., Duvail, C., Nehlig, P., Sagna, S.R., Serrano, O., Ligno, G. and Seck, D. (2009) Carte géologique du Sénégal à 1/500.000, Feuille Ouest. Première édition 03/2009.

[7] Muñoz, P., Letelier, V., Bustamante, M.A., Marcos-Ortega, J. and Sepúlveda, J.G. (2020) Assessment of Mechanical, Thermal, Mineral and Physical Properties of Fired Clay Brick Made by Mixing Kaolinitic Red Clay and Paper Pulp Residues. Applied Clay Science, 198, Article ID: 105847. https://doi.org/10.1016/j.clay.2020.105847

[8] Arsenovic, M., Stankovic, S., Radojevic, Z. and Pezo, L. (2014) The Effects of Chemical Composition and Firing Temperature in Heavy Clay Brick Production-Chemometric Approach. Interceram-International Ceramic Review, 63, 26-29. https://doi.org/10.1007/BF03401031

[9] Charai, M., Sghiouri, H., Mezrhab, A., et al., (2020) Comparative Study of a Clay before and after Fired Brick-Making Process. Materials Today. Proceedings, 31, S103S108. https://doi.org/10.1016/j.matpr.2020.06.250

[10] NF P 94-050 (1995) Détermination de la teneur en eaux pondérale-Méthode par étuvage.

[11] NF P 94-054 remplacé par NF EN ISO 17892-3 (2015) Reconnaissance et essais géotechniques-Essais de laboratoire sur les sols-Partie 3: Détermination de la masse volumique des particules solides Décembre.

[12] NF EN ISO 17892-4 (2018) Reconnaissance et essais géotechniques-Essais de laboratoire sur les sols-Partie 4: Détermination de la distribution granulométrique des particules.

[13] NF EN ISO 17892-12 (2018) Reconnaissance et essais géotechniques-Essais de laboratoire sur les sols-Partie 12: Détermination des limites de liquidité et de plasticité-Reconnaissance et essais géotechniques-Essais de laboratoire sur les sols- Partie 12: Détermination des limites de liquidité et de plasticité.

[14] NF P94-048 (1996) Détermination de la teneur en carbonate-Méthode du calcimètre.

[15] NF P94-068 (1998) Mesure de la capacité d'adsorption de bleu de méthylène d'un sol ou d'un matériau rocheux-Détermination de la valeur de bleu de méthylène d'un sol ou d'un matériau rocheux par l'essai à la tâche.

[16] NF P 13-301 (1974) Critères d'aspects physiques des briques en terre cuite.

[17] NF EN 771-1+A1/CN (2017) Spécifications pour éléments de maçonnerie-Partie 1: Briques de terre cuite-Complément national à la NF EN 771 1+A1:2015. 
[18] NF EN 772-11 (F) (2011) Détermination de l'absorption de l'eau par capillarité des éléments de maçonnerie en terre cuite.

[19] NF EN 772-1 (2011) Méthode d'essai des éléments de maçonnerie, partie 1: Détermination de la résistance à la compression.

[20] Casagrande, A. (1932) Research on the Atterberg Limits of Soil. Public Roads, 13, 121-136.

[21] Bhattarai, J., Ghale, D.B., Chapagain, Y.P., Bohara, N.B. and Duwal, N. (2018) Study on the Physical and Mechanical Properties of Ancient Clay Brick Samples of Kathmandu Valley, Nepal. Tribhuvan University Journal, 32, 1-18. https://doi.org/10.3126/tuj.v32i2.24699

[22] Johari, I., Jaya, R.P., Said, S., AbuBakar, B.H. and Ahmad, Z.A. (2011) Chemical and Physical Properties of Fired-Clay Brick at Different Type of Rice Husk Ash. International Conference on Environment Science and Engineering, 8, 171-174.

[23] ASTM Standard C618 (1980) Spécification de la perte au feu des éléments de maçonnerie en terre cuite.

[24] Muñoz, P., Mendívil, M.A., Letelier, V. and Morales, M.P. (2019) Thermal and Mechanical Properties of Fired Clay Bricks Made by Using Grapevine Shoots as Pore Forming Agent. Influence of Particle Size and Percentage of Replacement. Construction and Building Materials, 224, 639-658.

https://doi.org/10.1016/j.conbuildmat.2019.07.066

[25] NF DTU 20.1 (2008) Ouvrages en maçonnerie de petits éléments-Parois et murs Partie 1-1: Cahier des clauses techniques types.

[26] NF DTU 20.13 (2008) Cloisons en maçonnerie de petits éléments. 